\title{
VOC measurements within a boreal forest during spring 2005: on the occurrence of elevated monoterpene concentrations during night time intense particle concentration events
}

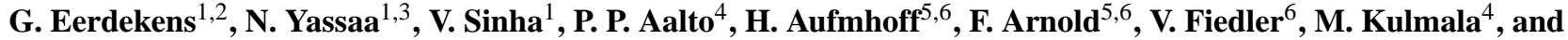 \\ J. Williams ${ }^{1}$ \\ ${ }^{1}$ Air Chemistry Department, Max-Planck Institute of Chemistry, Mainz, Germany \\ ${ }^{2}$ Plant and Vegetation Ecology, University of Antwerp, Wilrijk, Belgium \\ ${ }^{3}$ Faculty of Chemistry, University of Sciences and Technology Houari Boumediene, Algiers, Algeria \\ ${ }^{4}$ Department of Physics, University of Helsinki, Helsinki, Finland \\ ${ }^{5}$ Atmospheric Trace Gases and Ions, Max-Planck-Institute for Nuclear Physics, Heidelberg, Germany \\ ${ }^{6}$ Atmospheric trace gases, Institute of Atmospheric Physics, DLR, Oberpfaffenhofen-Wessling, Germany
}

Received: 13 May 2009 - Published in Atmos. Chem. Phys. Discuss.: 4 June 2009

Revised: 7 October 2009 - Accepted: 9 October 2009 - Published: 3 November 2009

\begin{abstract}
In this study we present measurements of selected trace gases and aerosols made in a boreal forest during the BACCI-QUEST IV intensive field campaign in Hyytiälä, Finland in April 2005. Springtime diel and vertical variations of VOCs are discussed in connection with the variations in other trace gases and with the prevailing meteorological conditions. A daytime and a nighttime event have been analysed in detail. The nighttime particle event occurred synchronously with huge increases in monoterpenes, while the second event type involved nucleation and was anti-correlated with sulphuric acid. Here we discuss the possible origins of these two distinct forms of aerosol production at the Hyytiälä site using the measurement data, air mass back trajectories and the optical stereoisomery of monoterpenes. Optical stereoisomery is used in source identification to distinguish between unnatural and natural monoterpene emissions.
\end{abstract}

\section{Introduction}

Boreal coniferous forests ring much of the region immediately south of the Arctic Circle and are comparable in size $\left(15\right.$ million $\left.\mathrm{km}^{2}\right)$ to that of global rainforest $\left(17\right.$ million $\left.\mathrm{km}^{2}\right)$.

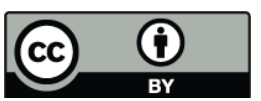

Correspondence to: G. Eerdekens (eerdekns@mpch.mainz.mpg.de)
They have been shown to profoundly influence regional atmospheric chemistry through the emission of reactive trace gases such as monoterpenes e.g. (Bäck et al., 2005; Räisänen et al., 2009; Spanke et al., 2001). During the atmospheric oxidation of monoterpenes, products with low vapour pressure such as organic acids can be produced, which can in turn condense to the aerosol phase. The role of these organics in new particle formation has been the subject of considerable research activities in recent years (e.g. Anttila et al., 2005; Bonn et al., 2008a; Tunved et al., 2006; Yu et al., 1999 and references therein), but is not fully understood. There are only a few studies reporting on night time new particle formation events (e.g. Junninen et al., 2008; Lee et al., 2008). In terms of chemical composition, newly formed ultrafine atmospheric aerosols are poorly characterized and there is currently insufficient information concerning organic species participating in secondary aerosol formation (e.g. Shimmo et al., 2004).

It has been established that the aerosols affect the radiative budget of the region (Kurten et al., 2003; Tunved et al., 2006) and the boreal forest in Finland has been reported to sustain $1000-2000$ particles $/ \mathrm{cm}^{3}$ by gas to particle conversion in the climatically relevant size range of $40-100 \mathrm{~nm}$.

The process of atmospheric particle production through nucleation and subsequent condensation growth has been shown to occur all over the world (Kulmala and Kerminen, 2008; Kulmala et al., 2004). The different environmental conditions and locations include e.g., in the free troposphere

Published by Copernicus Publications on behalf of the European Geosciences Union. 


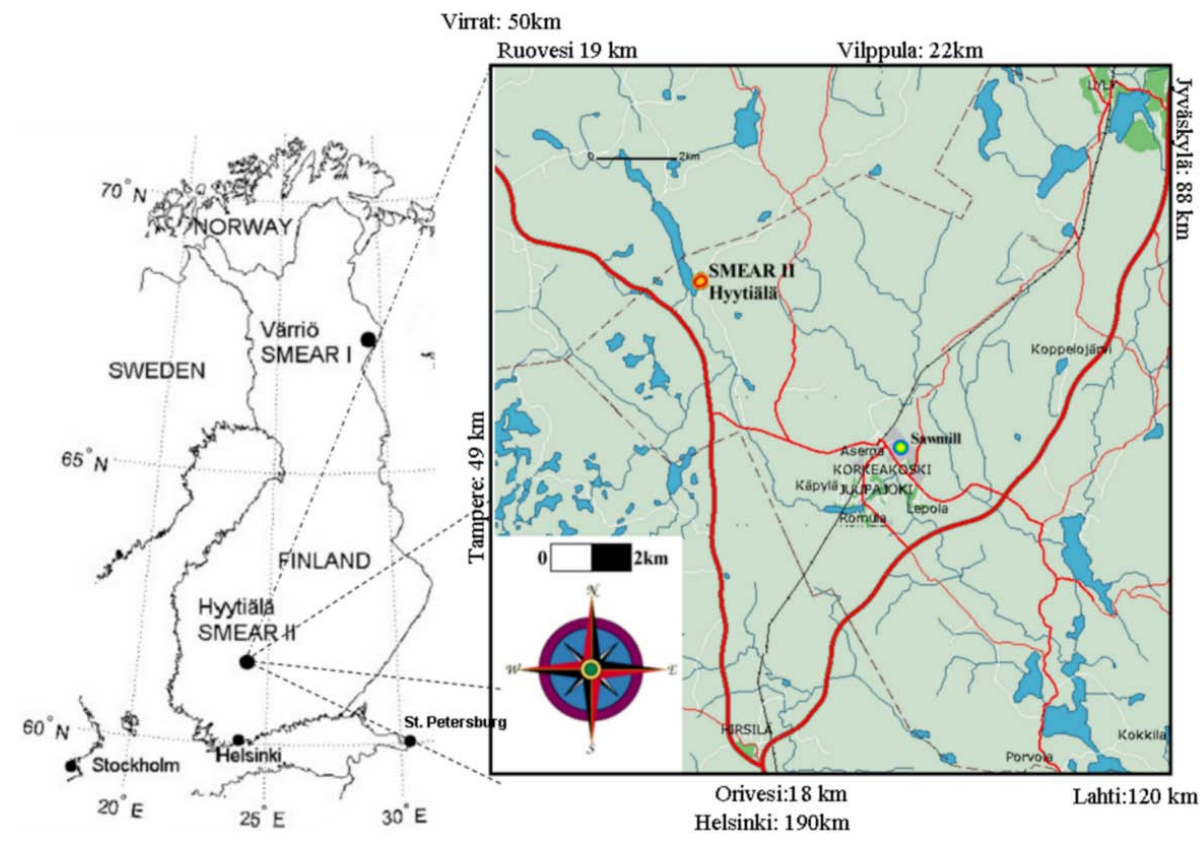

Fig. 1. Location of Hyytiälä on the map with its surrounding settlements and cities.

(Raes et al., 1997; Weber et al., 1999), in coastal zones (O'Dowd et al., 2002), in the continental boundary layer (Birmili et al., 2002), and in particular, over boreal forests e.g. (Dal Maso et al., 2005; Kulmala et al., 2001b). These nucleation events occur on a large horizontal scale in the order of several hundreds of kilometres, and have been detected simultaneously at sites $2000 \mathrm{~km}$ apart (Vana et al., 2004). A limited number of field studies on newly formed particles (3-5 nm) e.g. (Kulmala et al., 2001b) have concluded that the observed particles were primarily composed of high molecular weight oxidised organic species, such as cis-pinonic acid and pinic acid, produced by ozone induced oxidation of monoterpenes. Sulphate/organic mixtures have also been implicated in such new particle formation (Marti et al., 1997). The results of a study by Zhang et al. (2004) imply that the interaction between organic and sulphuric acids promotes efficient formation of organic and sulphate aerosols. It remains an open question whether organics are only involved in the growth of stable clusters, or if they can also influence the cluster formation.

In this study we present measurements of trace gases and aerosols made in a boreal forest during the "Biosphere - Aerosol - Cloud - Climate Interactions - Quantification of Aerosol Nucleation in the European Boundary Layer (BACCI/QUEST IV) intensive field campaign in Hyytiälä, Finland in April-May, 2005. The measurement period marked the transition from cold winter temperatures to more temperate spring temperatures. This is a particularly interesting period to examine and to compare with previous measurements, since most previous measurements have been taken in the summer e.g. (Haapanala et al., 2007; Hakola et al., 2003; Rinne et al., 2005). Several aerosol nucleation events have been analysed by Riipinen et al. (2007) for this campaign and the authors concluded that the main process limiting the observable particle formation was the competition between the growth of the freshly formed particles and their loss by scavenging, rather than the initial particle production by nucleation of sulphuric acid. Other particle formation events, in which sulphuric acid and water vapour are not key components, occurred synchronously with rapid and unexpectedly strong increases in monoterpenes. In this study, we examine the variations of VOC and particles during the spring campaign and identify two distinct types of aerosol production at the Hyytiälä site. Additionally, the enantiomeric determination of monoterpenes emitted by boreal trees (Yassaa and Williams, 2007) has been used to identify the source type.

\section{Site description}

The data presented here were collected at the "Station for Measuring Forest Ecosystem-Atmosphere Relations" (SMEAR II) at Hyytiälä $\left(61^{\circ} 51^{\prime} \mathrm{N}, 24^{\circ} 17^{\prime} \mathrm{E}\right)$, in southern Finland (see Fig. 1). The site is $230 \mathrm{~km}$ north of Helsinki, $180 \mathrm{~m}$ above sea level and surrounded by boreal forest (Hari and Kulmala, 2005; Vesala et al., 1998). The predominant tree species is Scots pine (Pinus sylvestris) with some spruce (Picea abies), aspen (Populus sp.) and birch (Betula sp.). Anthropogenic influences at the site are generally low, particularly when the wind comes from the sparsely populated northern sector. Incidental pollution from forest management 
activities is possible. The main road passing a few kilometres from the station to the southwest, and the cities of Tampere (pop. $\sim 205000 ; 391 \mathrm{inh} . / \mathrm{km}^{2}, 49 \mathrm{~km}$ to the south west) and Jyväskylä (pop. $84000 ; 610 \mathrm{inh} . / \mathrm{km}^{2}, 88 \mathrm{~km}$ to the northeast) can sometimes influence the site (see Fig. 1). Minor influences were expected from the few nearby settlements with low population densities (generally $<\sim 17 \mathrm{inh} . / \mathrm{km}^{2}$ ).

\section{Experimental}

At the SMEAR II station in Hyytiälä, a $74 \mathrm{~m}$ high mast is used for long-term measurements of meteorological, physical, and chemical parameters as a function of height (4.2, $8.4,16.8,33.6,50.4$, and $67.2 \mathrm{~m}$ ). These measurements include trace gases such as $\mathrm{NO}, \mathrm{NO}_{2}, \mathrm{SO}_{2}, \mathrm{CO}, \mathrm{CO}_{2}$ and $\mathrm{O}_{3}$; temperature, humidity, wind speed and wind direction and radiative measurements. A more detailed description of the site is given in Hari and Kulmala (2005). For the VOC measurements, a smaller mast was constructed circa $100 \mathrm{~m}$ from the aforementioned main SMEAR II measurement tower and circa $25 \mathrm{~m}$ from where the aerosol measurements were made. Gas phase sulphuric acid measurements were made from another nearby cottage. All these measurements were conducted within $100 \mathrm{~m}$ radius of the SMEAR II tower. Thus, for the interpretation of the observations all the three inlets are considered to be co-located. VOCs were quantified using a Proton Transfer Reaction Mass Spectrometer (PTR-MS), a Thermo Desorption-Gas Chromatography Mass Spectrometer (TD-GC-MS) and a Methane and Total Non Methane Hydrocarbon (NMHC) analyser.

\subsection{VOC-measurements}

The VOC measurements were made at heights of 2.1, 4.6, 8.2 and $11.8 \mathrm{~m}$ above the forest floor. While the lowermost level was below the leaved branches, the $8.2 \mathrm{~m}$ level was in the centre of the foliage and the uppermost inlet was located in the canopy crown. The tree tops were generally around 14-16 m. A single main pump was used to draw ambient air through six parallel PFA Teflon inlet lines. The length of each $6.35 \mathrm{~mm}$ i.d. inlets was $25 \mathrm{~m}$ to ensure identical residence times. Each inlet line was shrouded with black tubing to minimise any potential light induced artefacts within the lines. To prevent condensation, the lines were insulated. The flow per inlet line was restricted to a continuous 4.3 standard $\mathrm{L} \mathrm{min}^{-1}$ resulting in inlet residence times of air of $\sim 11 \mathrm{~s}$. Each of the VOC measurement techniques is described briefly in the following sections.

\subsubsection{Proton Transfer Reaction Mass Spectrometer (PTR-MS)}

The PTR-MS system used here has been described elsewhere (Eerdekens et al., 2009) and details of the general technique summarized most recently in Blake et al. (2009). Measurements were performed at 2.1 mbar drift tube pressure isothermally controlled at $45^{\circ} \mathrm{C}$. The PTRMS calibration factors have been corrected for humidity dependence. The time resolution for the PTR-MS was $50 \mathrm{~s}$ with dwell times of $1-2 \mathrm{~s}$ per mass. The total measurement error for $\alpha$-pinene ranged from $40 \%$ (at $0.15 \mathrm{ppbv}$ ) to $4.3 \%$ (at $15.0 \mathrm{ppbv}$ ); for methanol from $50 \%$ (at $0.7 \mathrm{ppbv}$ ) to $14 \%$ (at $5.0 \mathrm{ppbv}$ ); acetone $14 \%$ (at $0.4 \mathrm{ppbv}$ ) to $5 \%$ (at $2.5 \mathrm{ppbv}$ ); acetonitrile $100 \%$ (at 0.05 ppbv) to $40 \%$ (at $0.14 \mathrm{ppbv}$ ), and for toluene from $50-10 \%$ for volume mixing ratios between $0.1-0.45 \mathrm{ppbv}$.

If noise at each channel is taken as the signal observed upon sampling zero air (sampling with a catalytic converter in-line), the detection limits for the unsmoothed data using a threshold of 3 signal-to-noise ratio were $60 \mathrm{pptv}$ ( $\alpha$-pinene), $200 \mathrm{pptv}$ (methanol), $42 \mathrm{pptv}$ (acetone), $18 \mathrm{pptv}$ (acetonitrile), and 24 pptv (toluene).

At a rate of approximately $50 \mathrm{~s}$ per measurement cycle and 40 measurement cycles per level, the PTRMS sampling interval per level was $\sim 30 \mathrm{~min}$ from 17 April to 24 April. The PTR-MS sequentially monitored at all the aforementioned measuring heights, whereas the TD-GCMS and NMHC systems sampled from $8.2 \mathrm{~m}$. From 24 to 29 April all 3 instruments sampled from the $8.2 \mathrm{~m}$ level only.

\subsubsection{Thermo Desorption-Gas Chromatography Mass Spectrometer (TD-GCMS/SPME)}

On-line adsorption/thermal desorption was conducted using a gas chromatograph (GC 6890A) coupled to a Mass Selective Detector (MSD 5973 inert), both Agilent Technologies. The TD-GC-MS as used during this campaign is described elsewhere Williams et al. (2007). The MSD was operated in scan mode (20-250 amu) for the identification of compounds and in SIM mode for their quantification. Monoterpenes which differ from one another only in the way the atoms are oriented in space and consequently are non-superposable mirror-images of one another, better known as chiral monoterpenes or enantiomeric monoterpenes were separated using a beta-cyclodextrin capillary column (Cyclodex-B, $30 \mathrm{~m}$-long, $0.256 \mathrm{~mm}$ I.D., $0.25 \mu \mathrm{m}$ film thickness) supplied by J \& W Scientific (Folsom, CA, USA). The internal coating was composed of a permethylated $\beta$-cyclodextrin dissolved into a cyanopropyl-dimethyl polysiloxane liquid. The overall analysis time was $52 \mathrm{~min}$ with a precision error of 5-10\% and accuracy against a monoterpene gas standard of 5\% (Apel-Riemer Environmental Inc., Denver, Colorado, USA). Retention time confirmation of individual enantiomeric and non-enantiomeric monoterpenes was performed by analyzing pure standards under the same conditions. The elution order of enantiomers was further confirmed by comparison with previous work Yassaa and Williams (2005) and from the literature. Subsequent experiments designed to study the enantiomeric composition of monoterpenes in the emission of natural and 
damaged Scots pine have been conducted with solid-phase microextraction (SPME) combined with dynamic branch enclosure cuvettes and enantioselective GC-MS (for details see Yassaa and Williams, 2007) simultaneously with TD-GCMS.

\subsubsection{Methane and Total Non Methane Hydrocarbon Analyser $\left(\mathrm{CH}_{4}\right.$ and $\left.\mathrm{NMHC}\right)$}

Methane and total non-methane hydrocarbons were measured using a commercial gas chromatograph equipped with a flame ionization detector (Model 55C, Thermo Electron Corporation, Massachusetts, USA). Upon complete elution of methane in $\sim 17 \mathrm{~s}$, the GC column is back flushed by the carrier gas $\left(\mathrm{N}_{2}\right)$ and the non methane hydrocarbons are carried to the flame ionization detector (FID) for detection. The signal of the FID NMHC-channel is calibrated for propane and reported in propane equivalents, which can then be converted to parts per billion carbon (ppbC). The analysis time is $70 \mathrm{~s}$ while the accuracy and precision is $\pm 2 \%$ of the measured value. The detection limit is $20 \mathrm{ppb}$ for methane and $150 \mathrm{ppbC}$ for the non-methane hydrocarbons. Methane measurements conducted with this instrument in the boreal and tropical forests have been described in Sinha et al. (2007)

\subsection{Ancillary measurements}

\subsection{1 $\mathrm{H}_{2} \mathrm{SO}_{4}$ measurements}

Gaseous sulphuric acid measurements were performed by MPIK Heidelberg (Fiedler et al., 2005) using a chemical ionization mass spectrometer (CIMS) instrument developed and built by MPIK, Heidelberg. Reagent ions of the type $\mathrm{NO}_{3}^{-}\left(\mathrm{HNO}_{3}\right)_{n}$ (n mostly 1 ) are produced in the ion source and subsequently introduced into the flow reactor. Instrumental details have been described elsewhere (Hanke et al., 2002). $\mathrm{H}_{2} \mathrm{SO}_{4}$ molecules in the ambient air, are passed through the flow reactor, undergo ion-molecule reactions and the mass spectrometer measures the abundance ratio of product and reagent ions. The detection limit of $\mathrm{H}_{2} \mathrm{SO}_{4}$ was $2 \times 10^{5} \mathrm{~cm}^{-3}$ corresponding to an atmospheric mole fraction of 8 ppqv. The time resolution of the $\mathrm{H}_{2} \mathrm{SO}_{4}$ measurements is better than $10 \mathrm{~s}$, but the $\mathrm{H}_{2} \mathrm{SO}_{4}$ concentrations presented here were integrated over $200 \mathrm{~s}$ to reduce statistical error. The measurements bear an uncertainty of $\pm 30 \%$ to the actual reading (Fiedler et al., 2005).

\subsubsection{Aerosol measurements}

Aerosols at Hyytiälä were measured by numerous instruments operated by the University of Helsinki. An aerodynamic particle sizer, (TSI3321) was used to count aerosol particles in the size range $0.7 \mu \mathrm{m}$ to $20 \mu \mathrm{m}$ while a differential mobility particle sizer (DMPS) instrument described by Aalto et al. (2001) measures the number of particles in the diameter range $3 \mathrm{~nm}$ to $850 \mathrm{~nm}$. The total aerosol number concentration refers to the integrated $d N / d \log D_{p}$ over the DMPS-measurement range. The precision for the DMPS-measurements was calculated to be $4-10 \%$ on the total aerosol number concentration and include counting statistics, flow rate errors, detection efficiency errors, the differential mobility analyser dimension errors, and errors for temperature and pressure.

\subsubsection{Other trace gas measurements}

$\mathrm{H}_{2} \mathrm{O}$ and $\mathrm{CO}_{2}$ concentrations were measured on all levels at SMEAR II with an infrared light absorption analyser (URAS 4); $\mathrm{O}_{3}$ concentration with ultraviolet light absorption analyser (TEI 49C) and CO with infra red absorption (Horiba APMA 360). The trace gases $\mathrm{SO}_{2}$ and $\mathrm{NO}_{\mathrm{x}}$ were measured by UV fluorescence (TEI 43CTL) and chemiluminescence (TEI 432CTL), respectively. The time resolution was $1 \mathrm{~min}$ for all analysers. Thus within $30 \mathrm{~min}$, parameters were measured 5 times at each height. For a detailed description see Kulmala et al. (2001). The measurement precision is expressed as the standard deviation $(1 \sigma)$ of the signal while sampling calibration gas and amount to $\sim 0.05$ $\mathrm{g} \mathrm{H}_{2} \mathrm{O} / \mathrm{m}^{3}, \sim 0.1 \mathrm{ppm} \mathrm{CO} \mathrm{CO}_{2}, \sim 0.5 \mathrm{ppb} ; \mathrm{O}_{3}, \sim 0.05 \mathrm{ppb} \mathrm{SO}_{2}$, $\sim 0.05 \mathrm{ppb} \mathrm{NO}$, and $\sim 6 \mathrm{ppb}$ of $\mathrm{CO}$. The measurement accuracy amounts to $0.5 \mathrm{~g} / \mathrm{m}^{3}$ for $\mathrm{H}_{2} \mathrm{O}, 5 \mathrm{ppm}$ for $\mathrm{CO}_{2}, 1 \mathrm{ppb}$ for $\mathrm{O}_{3}, 0.1 \mathrm{ppb}$ for $\mathrm{SO}_{2}, 0.1 \mathrm{ppb}$ for $\mathrm{NO}_{\mathrm{x}}$, and $10 \mathrm{ppb}$ for $\mathrm{CO}$. These values are based on the observed changes of the signal offsets between successive calibration checks. Relative humidity was calculated as the ratio between the measured $\mathrm{H}_{2} \mathrm{O}$ concentration (converted to vapour pressure) and the saturation vapour pressure (dew point temperature was only measured at $23.3 \mathrm{~m}$ ) calculated from the measured air temperature with an accuracy of $2 \%$ absolute to the actual reading (P. Keronen, personal communication, 2009).

\section{General meteorology}

Figure 2 shows the basic meteorological parameters measured at the SMEAR II main mast during the campaign, along with the particle number concentration (black solid line). Gaps in the data are due to occasional failures in the data logging system of SMEAR II. During April the wind blew predominantly from the relatively unpopulated north (15-24 April and 29 April-2 May) and from the southeast (26-28 April). The temperature varied from +5 to $+13^{\circ} \mathrm{C}$ by day and from -5 to $+5^{\circ} \mathrm{C}$ by night, while the humidity ranged from 25 to $100 \%$. These conditions are typical of springtime in Finland. Lower temperatures were associated with periods of unvarying Arctic winds (higher wind speeds on all levels), whereas somewhat higher temperatures and pressures were reached during weak south-easterly winds. The precession of temperature and pressure indicate that a series of synoptic features have crossed the site in this period, only a few short-term precipitation events 


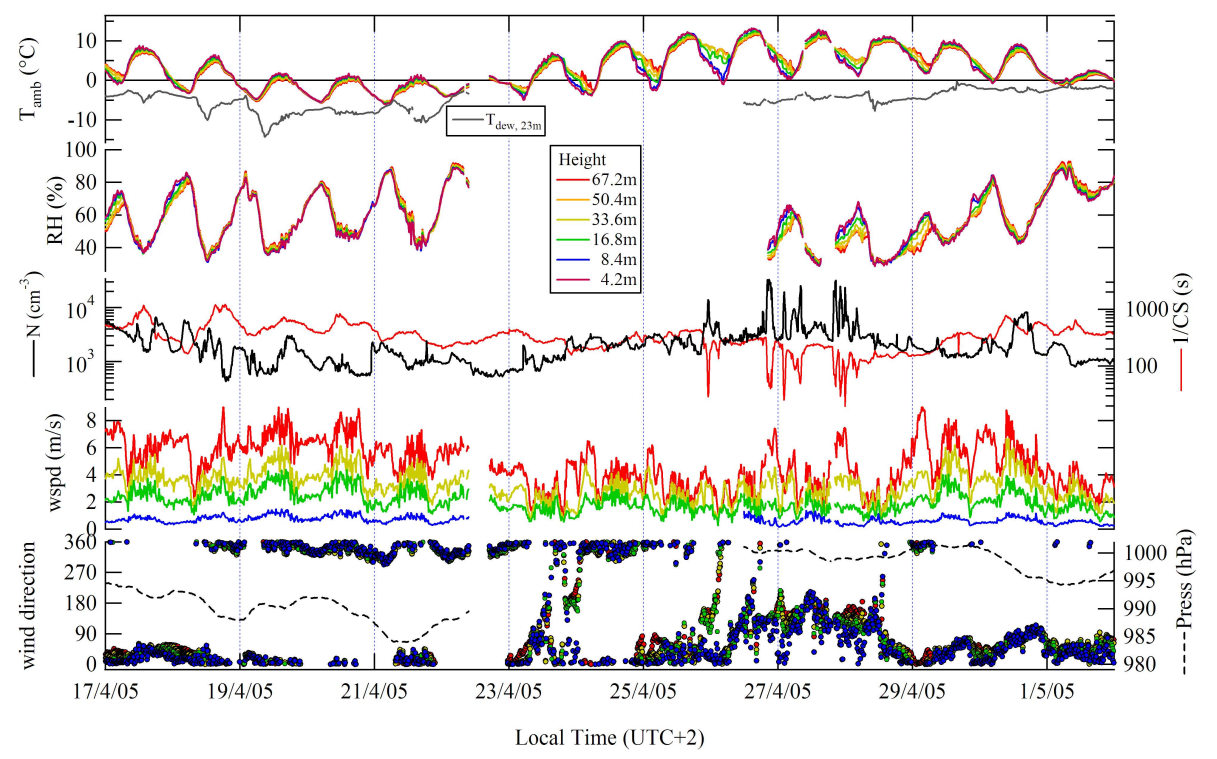

Fig. 2. Time series of basic meteorological parameters from the SMEAR II's main mast (74 m) and aerosol total number concentration over the measurement range of the DMPS-analyser (left) and 1/Condensational Sink (right). Gaps in data due to data logger failure.

were observed during the campaign (19-22 April, occasionally snow, no rain). From Fig. 2, a gradual rise in temperature throughout the campaign can be ascertained, and a slow thawing of the ground and the ice covered lakes was observed in this time.

Balloon soundings of temperature and pressure made at the site between 23 and 30 April, mostly in the early morning and early evening, indicated clear nocturnal inversions. Although the development of the nocturnal boundary layer (NBL) was not examined by the balloon soundings, the height of the NBL after midnight was to grow from $\sim 70 \mathrm{~m}$ at 20:00 (Local Time $=\mathrm{UTC}+2$ ) to $\sim 160 \mathrm{~m}$ at $\sim 05: 45 \mathrm{LT}$ determined by the earliest winching.

\section{Results}

This study focuses on the variations of the VOCs and particles during the spring campaign in Hyytiälä. In the first section, the VOC mixing ratios and particle concentrations are characterised as a function of time, meteorological parameters, diel cycle and height above ground. Subsequently in Sects. 5.4 and 5.5, two distinct particle burst events are selected and analysed using the VOC and gas phase $\mathrm{H}_{2} \mathrm{SO}_{4}$ measurements in order to investigate the probable cause of each event.

\subsection{General variation in VOC and aerosol concentra- tions}

From Figs. 2 and 3 it can be seen that the mixing ratios of many VOCs (e.g. acetone, methanol, acetaldehyde and monoterpenes) were observed to be higher during the warmer period of this campaign (23-30 April) than during the colder period (18-23 April). During the latter period, few VOCs showed a diel variation in their mixing ratios except for monoterpenes and methanol. Interestingly, monoterpenes were observed at mixing ratios between 0 and $16 \mathrm{ppbv}$ with a campaign average of $0.32 \mathrm{ppbv}$, and thereby comparable to the mixing ratios reported by Sellegri et al. (2005a, b) and by Ruuskanen et al. (2009) for the same site.

The mixing ratios of acetone (median $=1.27 \mathrm{ppbv}$ ) and methanol (median $=1.62 \mathrm{ppbv})$ are in agreement with values reported by Ruuskanen et al. (2009) and Taipale et al. (2008). However, while acetone values reported here $(0.75-1.40 \mathrm{ppbv})$ are in good agreement with previous measurements from the same location for March 2003 (Sellegri et al., 2005a), methanol values recorded in this study (0.60$2.10 \mathrm{ppbv}$ ) are markedly higher. Table 1 summarises the mixing ratios measured during this campaign with other literature values reported for Hyytiälä.

Acetonitrile mixing ratios were generally low (50 \pm 15 pptv). Higher values were observed on 28 and 29 of April with an average of $90 \pm 17$ pptv and a maximum of $130 \mathrm{pptv}$. Acetonitrile was in agreement with studies by Sellegri et al. (2005a) and Ruuskanen et al. (2009). Levels of the anthropogenic tracers benzene and toluene are similarly low (medians 96 pptv and 69 pptv, respectively) but show occasionally short term increases. Benzene mixing ratios are generally low in this region during spring, summer and autumn but higher during wintertime (Ruuskanen et al., 2009; Taipale et al., 2008). 
Table 1. Summary of VOC mixing ratios for April 2005 compared to other spring time measurements of VOCs observed at Hyytiälä, Finland.

\begin{tabular}{llccccc}
\hline & (ppbv) & This study colder period & This study warmer period & Sellegri et al., 2005b & Hellén et al., 2004 & Ruuskanen et al., 2009 \\
\hline $\mathrm{m} / \mathrm{z}$ & Compounds & $25 \mathrm{p}-75 \mathrm{p}$ & $25 \mathrm{p}-75 \mathrm{p}$ & $25 \mathrm{p}-75 \mathrm{p}$ & mean & $5 \mathrm{p}-95 \mathrm{p}$ \\
33 & Methanol & $0.64-1.00$ & $1.23-2.01$ & $0.23-0.42$ & $0.05-0.10$ & $0.31-1.74$ \\
42 & Acetonitrile & $0.03-0.05$ & $0.05-0.07$ & $0.02-0.05$ & 0.18 & $0.02-0.06$ \\
45 & Acetaldehyde & $0.14-0.21$ & $0.21-0.32$ & $1.09-1.66$ & 0.52 & $0.40-1.31$ \\
59 & Acetone & $0.74-0.96$ & $1.21-1.40$ & & $0.02-0.10$ \\
69 & Isoprene & $0.04-0.08$ & $0.05-0.10$ & & $0.03-0.13$ \\
71 & MACR+MVK & $0.01-0.03$ & $0.02-0.04$ & & $0.06-0.11$ \\
79 & Benzene & $0.08-0.12$ & $0.08-0.13$ & & \\
93 & Toluene & $0.01-0.04$ & $0.03-0.07$ & $0.19-0.40$ & \\
137 & Monoterpenes & $0.06-0.18$ & $0.17-0.64$ & & $0.03-0.20$ \\
\hline
\end{tabular}

The results for acetaldehyde presented here are in good agreement with $24 \mathrm{~h}$ cartridge samples for March and April taken in 2003 by Hellén et al. (2004) who reported acetaldehyde mixing ratios between 0.09 and $0.28 \mathrm{ppbv}$ with an average of $\sim 0.18 \mathrm{ppbv}$ and to those reported by Ruuskanen et al. (2009) for springtime 2006-2007. Sellegri et al. (2005a) reported lower mixing ratios as shown in Table 1.

Ruuskanen et al. (2009) showed that the boreal forest is only a weak emitter of isoprene in springtime, approximately 10 times less than levels typically measured over the rainforest (Helmig et al., 1998; Zimmerman et al., 1988), and our data confirm these very low isoprene mixing ratios.

From Fig. 2 we note that the warmer period was characterised by elevated particle background concentrations in comparison to the cold period. The warmer period also exhibited comparatively more methanol relative to acetone than in the cold period.

From Fig. 2 we may compare the total particle concentration in the range of 3-850 nm detected by the DMPS and the inverse value of the condensational sink (CS, i.e. pre-existing aerosol particle surface) calculated for sulphuric acid according to Kulmala et al. (2001a) with the meteorological parameters. 1/CS describes the time, which a sulphuric acid molecule has until it collides with the next aerosol surface area. The diel cycle of $1 / \mathrm{CS}$ is characterised by lower values after midnight and a pronounced increase between sunrise and about 10:00 LT. Campaign median values of 1/CS varied between 300 and $400 \mathrm{~s}$ with higher variability during daytime (250-550 s, 25p-75p). Values have clearly been much lower $(<300 \mathrm{~s})$ between dusk on 25 April and dawn on 29 April still showing the same characteristic diel profile. Median values of $1 / \mathrm{CS}$ varied between 100 and $150 \mathrm{~s}$. This period shows elevated aerosol particle concentrations with several distinct events, defined as strong deviations from the underlying background. In particular, there is a broad event on the 30th of April (hereafter termed Event 1) during which particle concentrations increased from circa 1200 to 6000 particles $/ \mathrm{cm}^{3}$ for approximately $6 \mathrm{~h}$. Between the 25 th and the 28th of April a series of short, intense particle bursts occurred. In such events (hereafter collectively termed Event 2), particle concentrations were observed to increase by an order of magnitude over the background (circa $30000 \mathrm{~cm}^{-3}$ over $3000 \mathrm{~cm}^{-3}$ ).

Shown in Fig. 3 is $\mathrm{SO}_{2}$ whose predominant regional source is anthropogenic (e.g. fossil fuel burning). $\mathrm{SO}_{2}$ mixing ratios were highly variable exhibiting both daytime and night-time maxima up to 2 ppbv or $4.2 \times 10^{10}$ molec. $\mathrm{SO}_{2} / \mathrm{cm}^{3}$. This is in contrast to $\mathrm{H}_{2} \mathrm{SO}_{4}$ which showed a distinct diurnal cycle, see Fig. 4, with maxima up to $2 \times 10^{7} \mathrm{H}_{2} \mathrm{SO}_{4}$ molec./ $/ \mathrm{cm}^{3}$ for the period between the 17th of April and the 2nd of May.

Figure 4 shows the average $24 \mathrm{~h}$ or diel cycle in the net radiation, the potential temperature gradient and the mixing ratios of monoterpenes, methanol, acetaldehyde and sulphuric acid during the warmer period which is also the period with the strongest nocturnal inversions during this campaign. Although monoterpene emissions have been shown previously to be a function of the ambient temperature, with higher emission rates during the day (Janson, 1992; Janson and De Serves, 1999, 2001; Spanke et al., 2001), the monoterpene mixing ratios observed at Hyytiälä during spring were found to be higher at night. This is likely due to the formation of a shallow nocturnal inversion layer at night over the continuously emitting vegetation. Also Taipale et al. (2008) measured occasional higher night-time mixing ratios for monoterpenes, though these increases were much weaker than observed during this campaign. These short term peaks in the monoterpenes do not correlate well with the slowly changing temperature profile and will be studied in depth in the following section.

Sellegri et al. (2005a) reported that the VOC mixing ratios were driven by boundary layer dynamics. They showed diel cycles for many VOCs with higher night time mixing ratios.

Methane mixing ratios (not shown) ranged between 1.781.88 ppmv during the campaign with clear trends in the diel cycle. However, the diel cycle was different from that of any of the aforementioned VOCs and was not correlated with the strength of the nocturnal inversion. Mixing ratios increased at the onset of the NBL until the morning reaching maximum 


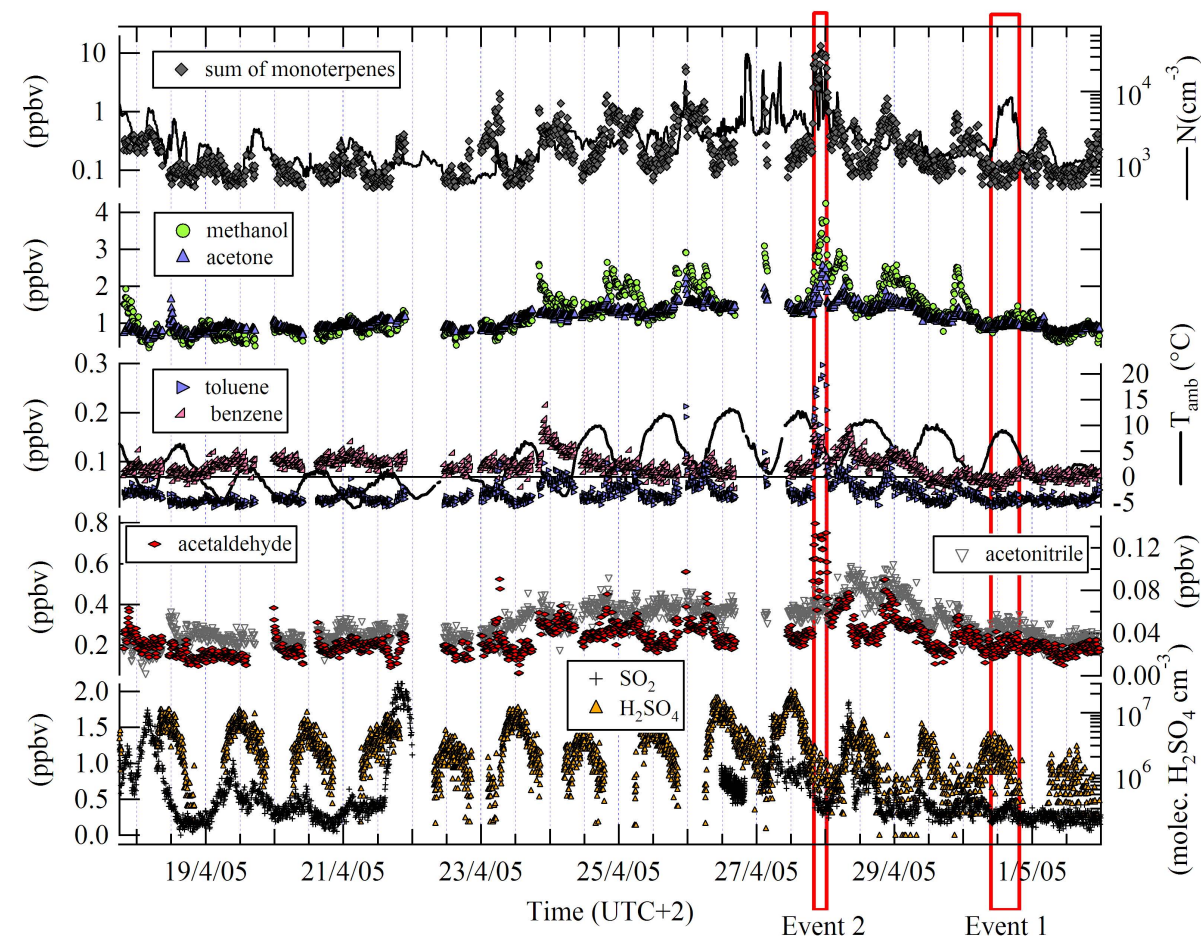

Fig. 3. Inorganic and organic trace gases ( $10 \mathrm{~min}$. avg.), total aerosol particle concentration measured for the springtime BACCI/QUEST IV campaign at Hyytiälä. Indicated are the windows for Event 1 and Event 2.

mixing ratios between 06:00 LT and 09:00 LT after which they declined to minimum values between $\sim 15: 00 \mathrm{LT}$ and $\sim$ 18:00 LT. Higher methane mixing ratios were generally observed when the wind blew from northwest to northeast.

\subsection{Vertical distribution of VOCs}

Vertical profiles of the VOCs were obtained by sampling over the 4 sampling levels previously described, from the evening of 17 April and before sunrise on 23 April. They are presented in Fig. 4 as 5p-95p box and whisker plots a) for methanol, acetone, the sum of monoterpenes and acetonitrile $\mathrm{b}$ ) benzene, toluene, isoprene and acetaldehyde with separate daytime (solid lines) and night-time (dashed lines) vertical profiles normalised to their daily average mixing ratios. The vertical gradients within the forest were not strong $(<15 \%)$ and were not really substantially different for day and night time, except for monoterpenes. Interestingly, acetone was the only tracer within this selected group of VOCs with higher mixing ratios on average during the day than during the night for the aforementioned period. VOC mixing ratios have mostly been correlated with a positive temperature gradient and thus controlled by the suppressed mixing during the night. Fallen needles may be the possible source of monoterpenes close to the ground. The concentration differences between below canopy and above is expected to be larger.

\subsection{VOCs and other trace gases during the particle events}

Two distinct particle events were selected for examination in this study: Event 1 (daytime: 30 April) was a threefold increase in particles lasting several hours; Event 2 (nighttime: $27-28$ April) was a series of short duration pulses, $\sim 10$ fold increases in the monoterpene mixing ratios and $\sim 10$ fold increases in the total particle concentration. In this section we examine the relationship between organic and inorganic compounds, and particles during these events.

Prior to the start of the VOC measurements, relatively strong nucleation events were observed almost every day in daylight between 28 March and 17 April, clearly discernible in DMPS spectra as the aerosol particle size distribution shifts from small $(<3 \mathrm{~nm})$ to larger aerosol particles (usually up to $100 \mathrm{~nm}$ ). Some of these events have been discussed in detail by Riipinen et al. (2007). Occasionally, a nucleation event extended into the following day resulting in a size distribution with two independent size modes. Between 19 April and 24 April, there was an absence of nucleation events and considerably fewer particles were counted in the range of $3 \mathrm{~nm}$ to $850 \mathrm{~nm}$. Back trajectories for this period indicate relatively steady Arctic winds crossing Finland. Daytime and night time temperatures did not differ much during this period preventing the formation of a strong temperature inversion in the surface layer. The vertical potential temperature 


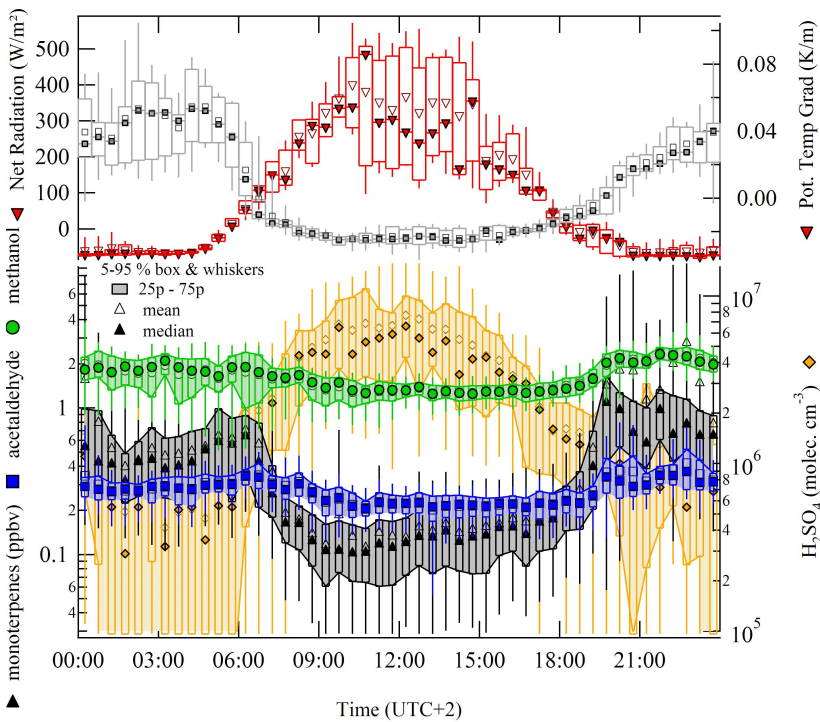

Fig. 4. Diel profiles of the net radiation, the potential temperature gradient, methanol, acetaldehyde, monoterpenes and sulphuric acid for the period between 23 and 30 April 2005 presented as 5-95 box and whisker plots.

gradients (indicated by the black dashed line scaled on the bottom right axis of Fig. 6) were $0.1 \mathrm{~K}$ per meter between the top of the canopy and $50 \mathrm{~m}$ measurement height in the night being strongest during the night of 25 April.

In the upper panel of Fig. 6, the number of particles counted for a certain size interval is quantitatively colour marked for intensities between 1 and $10^{5}$ particles per $\mathrm{cm}^{3}$ for 1 week of measurements in which Event 1 and Event 2 took place. A clear increase in intensity $\left(\mathrm{N}>3000\right.$ particles $\left./ \mathrm{cm}^{3}\right)$ for particles between $20 \mathrm{~nm}$ and $300 \mathrm{~nm}$ is visible between 25 April and noontime 29 April. During this period acetonitrile mixing ratios were 60 \pm 11 pptv and thereby higher than $35 \pm 10$ pptv observed between 17 and 23 April, indicating a minor influence of wood combustion. However, these low mixing ratios indicate that the source must have been distant to the site.

\subsection{Event 1 (daytime)}

Event 1 (30 April, 08:20 LT- 19:00 LT), shows clear particle growth starting above the smallest size classes in contrast to the nucleation events on 25, 26 and 27 of April, the latter being discussed in Riipinen et al. (2007). Although these 3 nucleation events have been characterised by growth, from particles $<3 \mathrm{~nm}$ rather than from $4 \mathrm{~nm}$ onward like Event 1 , their particle number concentrations were less than observed during Event 1.

Nucleation already started approximately $1 \mathrm{~h}$ before the slow increase in the total particle number concentration at 09:35 LT followed by very strong increase to a maximum of about $6000 \mathrm{~cm}^{-3}$ at 11:10LT. Between 12:30LT and
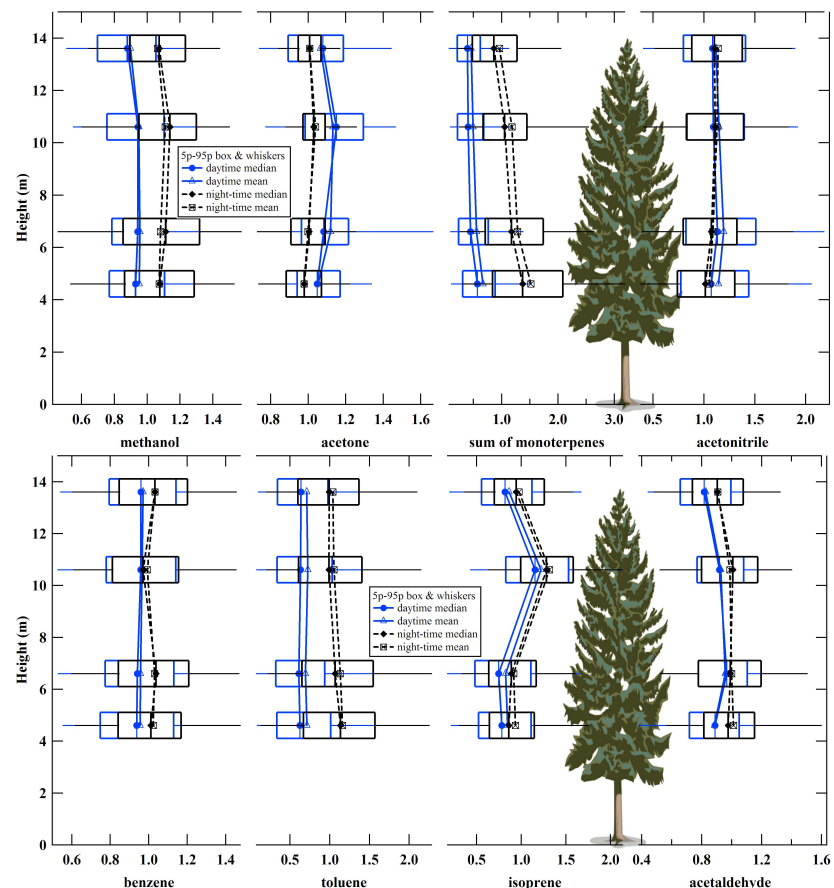

Fig. 5. Vertical profiles within the canopy for VOCs normalised to their daily average mixing ratio in $5 p-95 p$ box and whiskers for the period 17-23 April 2005.

17:00 LT, the increase in the particle concentration was considerably less. Daytime temperatures were higher at the surface than at the highest measurement level $(74 \mathrm{~m})$ (Fig. 7a) from which we may assume well mixed boundary layers.

Figure 6 shows that all nucleation events mentioned above have been clearly influenced by boundary layer conditions, as the growth of the aerosol particles and the concentration flagged after the onset of the NBL in the evening.

Monoterpene mixing ratios declined during the break-up of the NBL on 30 April to become rather constant around $0.2 \mathrm{ppbv}$ for the rest of the day. Thus they do not show any correlation with particle concentration changes associated with Event 1 (Fig. 7a).

Measured signals m/z 169 (pinonaldehyde), which could not be accurately converted into quantitative results due to a lack of a standard of monoterpenes oxidation products, have been shown to be mostly under the detection limit during Event 1. Uncalibrated signals for pinonaldehyde (m/z 169) measured at the time by the PTRMS instrument of the University of Helsinki are presented in Figs. 3 and 4 of Bonn et al. (2008b). Even though these measurements did not cover Event 1 in particular and mixing ratios were declining from elevated levels during the night preceding Event 1, it is probable that these low volatility products ended up in the particle phase. 


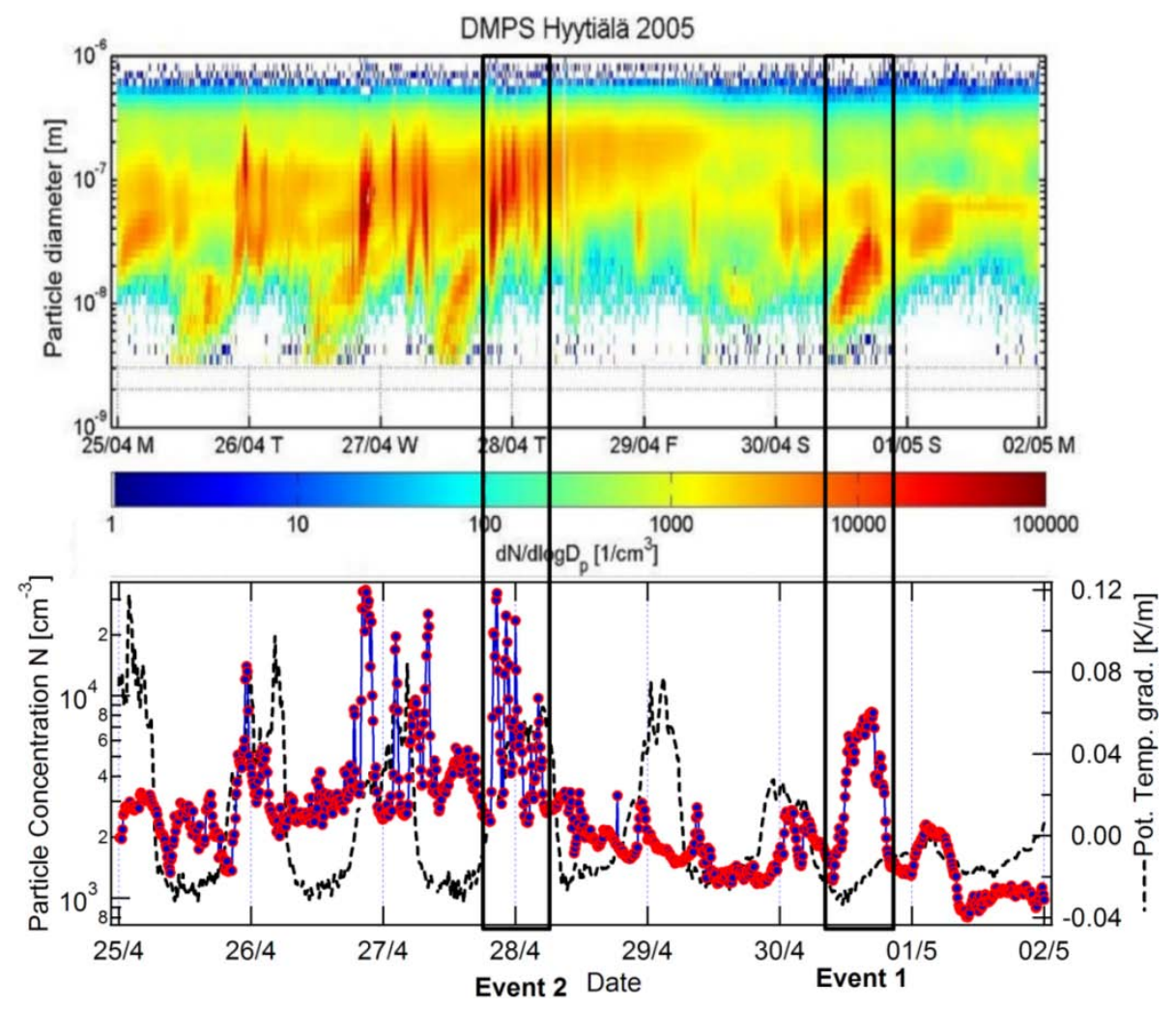

Fig. 6. Differential mobility size spectra between $3 \mathrm{~nm}$ and $850 \mathrm{~nm}$ for one week during which Event 1 and 2 occurred. Event 1 is a broad event on 30 April; Event 2 is a series of shorter, more intense particle bursts during the night of 27 to 28 April. Bottom panel shows the occurrence of the strong short-term increases in the total aerosol particle concentration (right-axis) with the potential temperature inversions (left-axis).

Mixing ratios of methanol, acetone and acetaldehyde (not shown), were observed to increase only slightly (few hundred pptv) until the onset of the NBL. The toluene to benzene ratio (not shown) varied between 0.1 and 0.8 throughout the day except between 12:00 LT and 13:00 LT when it exceeded 1 , indicating fresher anthropogenic pollution. Such fossil fuel combustion episodes may have introduced new aerosol particles for those formed by nucleation to collide with.

Methane mixing ratios decreased from $1.83 \mathrm{ppmv}$ to 1.79 ppmv throughout Event 1. Owing to the low chemical reactivity of methane (lifetime $\sim 9$ years), it is unlikely to have played a significant role in the nucleation process and this is also the case for the aforementioned VOCs. However, for every peak in the particle concentration during Event 1, there is a peak in the methane mixing ratio as well.

During this campaign, the wind speed was variable by day (enhanced mixing) and more constant by night (suppressed mixing). Nearer the ground the wind speed was lower, consistent with a surface friction resistance and with a much higher wind deflection relative to the pressure gradient wind above. Shown in Fig. $7 \mathrm{~b}$ is the wind direction at different levels including a level (at $16.8 \mathrm{~m}$ ) just above the canopy and the highest level (at $67.2 \mathrm{~m}$ ) which is the least affected by wind shear. It should be noted that one hour after the start of nucleation at 08:30 LT, there was very abrupt change in wind direction (by $\sim 25^{\circ}$ ) from North easterly during which nucleation took place, to North-North easterly on all measurement levels above the canopy. This suggests that SMEAR II had been located at the interface of two air masses and in one of these new particle formation had occurred while the other air mass favours particle growth. A slight shift in the air mass boundary relative to the location of SMEAR II could have made the difference between an event day and a non-event day. The particle growth in Event 1 appears to stop abruptly after about $8 \mathrm{~h}$ coincident with the onset of the NBL, shortly before sunset and the wind veered further to become easterly wind.

Figure $7 \mathrm{~b}$ also shows that at 09:35 LT wind speeds on all levels maximised (i.e. $\sim 10 \mathrm{~m} / \mathrm{s}$ at $67.2 \mathrm{~m}, \sim 6 \mathrm{~m} / \mathrm{s}$ at $16.8 \mathrm{~m}$ ) and halved over the course of Event 1 until 19:00 LT (= onset of the NBL). The highest total particle concentrations were observed when the wind direction was approximately $75 \pm 17^{\circ}$, and the enhanced particle event terminated when the wind direction shifted slightly to circa $100 \pm 17^{\circ}$. 

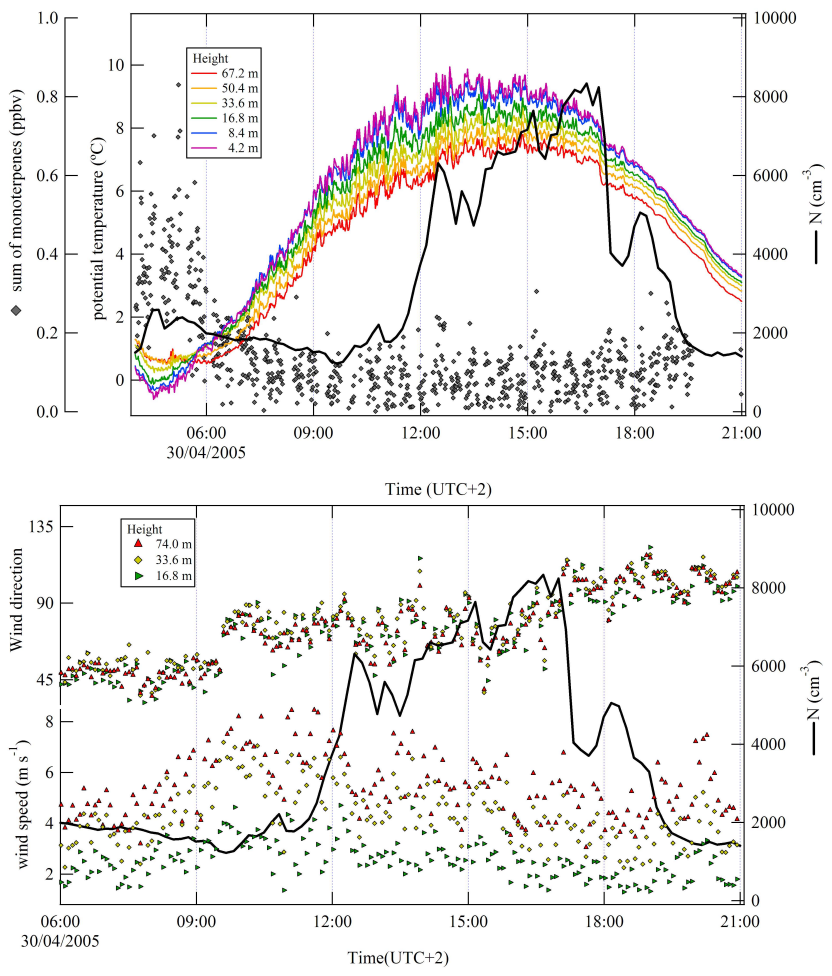

Fig. 7. Aerosol total concentration (black solid lines) in relation to (a) the monoterpenes mixing ratios measured at $8.2 \mathrm{~m}$ and the potential temperature; (b) wind direction and wind speed measured at SMEAR II for Event 1.

4-day backward trajectories ending at Hyytiälä every three hours on the 30th indicate that the air mass originated from the north, but turned northeasterly so that it crossed central Finland two days before arrival at the site. According to the NOAA Hysplit model, the air mass stayed closer to the surface in the two days before arrival than on the days before. The model did not indicate any significant difference in trajectories arriving before and those arriving after the start of Event 1.

$\mathrm{CO}_{2}$ is known to be removed from the atmosphere by vegetation during photosynthesis and a minimum in the daytime $\mathrm{CO}_{2}$ mixing ratios is observed. $\mathrm{CO}_{2}$ mixing ratios decreased from 404 ppmv at dawn to $394 \mathrm{ppmv}$ at the end of Event 1, but $\mathrm{CO}_{2}$ was not considered to be related to its occurrence (see Fig. 8), in contrast to Event 2 discussed below. $\mathrm{CO}_{2}$ mixing ratios were significantly higher within the canopy. Ozone mixing ratios were similar to those observed on the previous day when no nucleation event occurred. The difference in the ozone concentrations for more polluted to non-polluted airmasses measured during spring 2005 was about $50 \mathrm{ppbv}$ to $25 \mathrm{ppbv}$, respectively. Carbon monoxide (CO) data did not show signs of diel variation on Friday the 29th and Saturday the 30th of April but varied between 130 and 160 ppbv. $\mathrm{CO}$ mixing ratios (not shown) were somewhat lower between

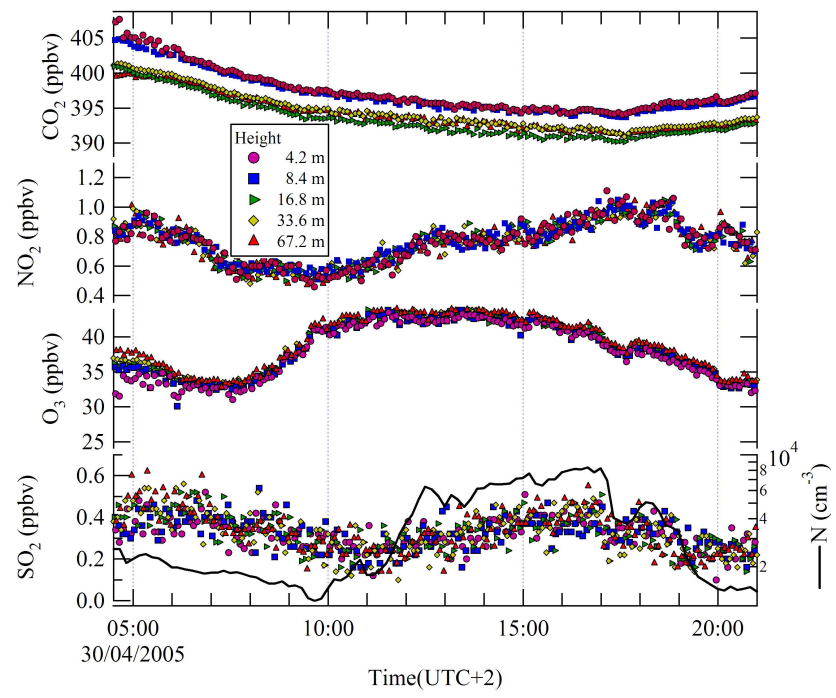

Fig. 8. $\mathrm{CO}_{2}, \mathrm{O}_{3}, \mathrm{NO}_{2}$ and $\mathrm{SO}_{2}$ mixing ratios in relation to the aerosol particle total concentration for Event 1.

09:00 LT and 15:00 LT. A typical commuter traffic related NO peak (not shown) was observed between 04:30 LT and 07:00 LT with maximum mixing ratios of $0.15 \mathrm{ppbv}$ around 06:00 LT (corresponding to slightly higher $\mathrm{CO}$ mixing ratios) and occurring under a declining total aerosol number concentration. No such clear peak in NO has been observed in the afternoon. Only in the evening, between 19:00 LT and 20:00 LT a similar peak up to $0.15 \mathrm{ppbv}$ NO was observed.

Several peaks in $\mathrm{NO}_{2}$ (up to $1.2 \mathrm{ppbv}$ ) have been observed during the night of 29 to 30 of April, each lasting several hours and coinciding with increases in the particle concentration of $1200 \mathrm{~cm}^{-3}$. The daytime $\mathrm{NO}_{2}$ peak (up to $1 \mathrm{ppbv}$ ) was not as narrow as the night time peaks and closely resembled the aerosol particle concentration (see Fig. 8). New particle formation by nucleation took place under a decline in $\mathrm{NO}_{2}$ whereas faster increase in the particle concentration took place under constantly increasing $\mathrm{NO}_{2}$ mixing ratios.

Radiative measurements (see top panel Fig. 9a) indicated that Event 1 took place under mostly clear sky conditions until 11:10 with a very brief disturbance slightly reducing the direct sunlight around 09:35 LT. Thereafter, the sky became overcast affecting both temperature and humidity. The relative humidity just above the canopy generally decreased from $84 \%$ at $04: 35 \mathrm{LT}$ to $44 \%$ at 13:30 LT, after which RH remained rather constant until 15:30 LT. The difference in RH from the lowest to the highest measurement level of SMEARII was about $5 \%$ over the entire day. The number concentration of particles between $6 \mathrm{~nm}$ and $25 \mathrm{~nm}$ increased right after nucleation. For the rest of the day there was little direct sunlight, and predominantly the number concentration of particles larger than $12 \mathrm{~nm}$ increased, whereas the number concentration of particles smaller than $12 \mathrm{~nm}$ decreased by scavenging. 
At 17:00 LT, a sudden increase in RH by 5\% and a change in the wind direction to the East occurred together with the large decrease in the number concentration of particles in the range $12-90 \mathrm{~nm}$.

The observed concentration of $\mathrm{SO}_{2}$ (mixing ratios $0.3-$ $0.6 \mathrm{ppbv}$ prior to nucleation shown in the bottom panel in Fig. 8) were 10000-60000 times higher than the concentration of its photo-oxidation product $\mathrm{H}_{2} \mathrm{SO}_{4}$ during the night, and 1000-10000 times higher during daytime of 30 April. $\mathrm{H}_{2} \mathrm{SO}_{4}$ showed maximum concentrations of $3.6 \times 10^{6}$ molecules $\mathrm{H}_{2} \mathrm{SO}_{4} / \mathrm{cm}^{3}$ just before 09:00 LT, followed by a decline during nucleation to $1.5 \times 10^{6}$ molecules $\mathrm{H}_{2} \mathrm{SO}_{4} / \mathrm{cm}^{3}$ until noontime. Ammonia (not shown) was only measured until 23 April as described by Riipinen et al. (2007) and references therein. They found no significant relation between the particle concentrations and ammonia for the nucleation events prior to the VOC measurements at Hyytiälä.

Figure 9a also shows a continuous decrease in the condensational sink (CS) prior to Event 1 followed by a continuous increase during and after nucleation with only minor fluctuations under overcast conditions. CS values decline during Event 1 from $3.3 \times 10^{-3} \mathrm{~s}^{-1}$ to $1.3 \times 10^{-3} \mathrm{~s}^{-1} \mathrm{~s}^{-1}$ and thus a lifetime of about $400 \mathrm{~s}$ which is commonly observed at Hyytiälä (median daytime values for first half of 2005 were $\left.(3.5 \pm 2.0) \times 10^{-3} \mathrm{~s}^{-1}\right)$. Even though there is no direct comparison with the growth rate for the smaller particles, the observed growth rate at size from $5 \mathrm{~nm}$ to $10 \mathrm{~nm}$ was $8.4 \mathrm{~nm} / \mathrm{h}$, which is in agreement with values indicated by Dal Maso et al. (2005) and Kulmala et al. (2004).

The contribution of sulphuric acid on the growth rate can be approximated to be around 5\% using the methods described by Kulmala et al. (2001b). In practise this indicates large organic contribution on the growth. On the other hand it seems to be probable that sulphuric acid will participate the atmospheric nucleation process, since the concentration of ultrafine particles is closely related to sulphuric acid concentration. Recently the atmospheric nucleation has been shown to occur around the size of $1.5 \mathrm{~nm}$ in Millikan diameter (Kulmala et al., 2007).

As a first approximation and in absence of real-time wind fields, plain fetch calculations were done for Event 1 on the assumption that the monitored air mass had been transported towards the site from the measured wind direction and speed. This assumption was supported by the 2-day steady back trajectories consistently following the same path on $3 \mathrm{lev}$ els $(100 \mathrm{~m}, 250 \mathrm{~m}$ and $500 \mathrm{~m})$ prior to arrival. Figure $9 \mathrm{c}$ shows that a tracer released three, six and nine hours back in time, could have been influenced at $33.6 \mathrm{~m}$ by sources between respectively 30 to $70 \mathrm{~km}, 60$ to $140 \mathrm{~km}$, and 90 to $220 \mathrm{~km}$ distant to the site. Tracers released at $16.8 \mathrm{~m}$ could have been affected by sources at 15 to $30 \mathrm{~km}, 30$ to $90 \mathrm{~km}$, and 60 to $130 \mathrm{~km}$ distant to the site, due to the higher surface friction. Clean air masses coming from the East-North East will have been impacted by emissions to some extent including organic and inorganic tracers such as $\mathrm{SO}_{2}$ that converts
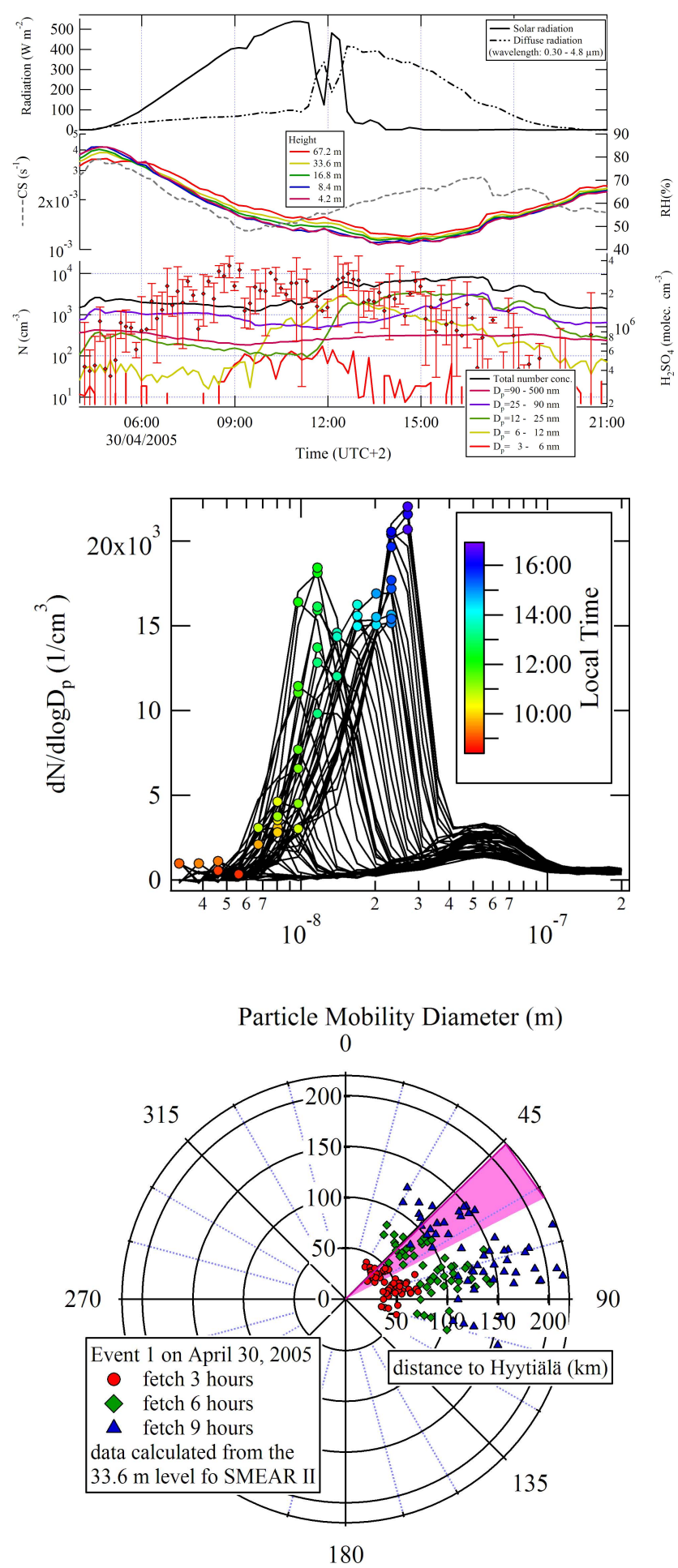

Fig. 9. (a) Radiation, $\mathrm{RH}, \mathrm{CS}$ and $\mathrm{H}_{2} \mathrm{SO}_{4}$ concentrations $( \pm 1 \sigma$ over the measurement interval of the DMPS) as function of time for Event 1. (b) Particle size distribution for Event 1. (c) Three, six- and nine-hour plain fetch calculated from $33.6 \mathrm{~m}$ wind data for Event 1 in kilometres to the site. Highlighted wind direction corresponds to the relative position of the big city Jyvaskyla and its airport, approximately $90 \mathrm{~km}$ away from Hyytiälä. 
into $\mathrm{H}_{2} \mathrm{SO}_{4}$. The organic mixing ratios in these air masses were low. Included along the air mass trajectory is the city of Jyväskylä and its industrial region at ca. $60^{\circ}$, and its airport at $49^{\circ}$ approximately $88 \mathrm{~km}$ and $95 \mathrm{~km}$ respectively away from Hyytiälä. We assume these to be emission sources of $\mathrm{SO}_{2}$ in the case of continuous transport of air masses from the NE sector.

In summary we note that Event 1 occurred by day in the absence of a temperature inversion. The event was very sensitive to changes in wind direction and to a lesser extent on wind speed. Event 1 took place under relatively elevated levels of ozone and slightly elevated $\mathrm{NO}_{\mathrm{x}}$, under slightly increased $\mathrm{CO}$, and under naturally declining $\mathrm{CO}_{2}$. Event 1 is characterised by an anti correlation of the particle number concentration with sulphuric acid, which in turn depends on the solar radiation and $\mathrm{SO}_{2}$ levels. No correlation with monoterpenes or other VOCs was found.

The production of the small particle $(<4 \mathrm{~nm})$ has occurred at some point upwind of the measurement station, but Event 1 still shows the remaining characteristics of a nucleation event.

\subsection{Event 2 (night-time)}

Event 2 refers to the series of intense particle bursts which occurred during the night of 27th to 28th of April 2005 under unusual meteorological conditions. Similar bursts to those observed in Event 2 occurred during the nights prior to Event 2 but could not be investigated in detail as the meteorological and trace gas dataset was incomplete.

The remarkably intense bursts were observed only a few hours after the onset of the NBL $(\sim 0.2 \mathrm{ppbv})$. Monoterpene mixing ratios increased to $\sim 7.1 \mathrm{ppbv}, \sim 10 \mathrm{ppbv}$ and $15.9 \mathrm{ppbv}$ and the corresponding particle concentrations were 18000,32000 and 25000 particles $/ \mathrm{cm}^{3}$ respectively (Fig. 10a). The absence of monoterpene mixing ratios during the next peak of 23500 particles/ $\mathrm{cm}^{3}$ was due to PTRMS system calibration. Subsequent peaks were much lower in particle concentration $\left(<10000\right.$ particle $\left./ \mathrm{cm}^{3}\right)$ and in monoterpenes $(<1.5 \mathrm{ppbv})$ around 1, 3 and 4 o'clock.

The bursts of aerosol particles were strongly correlated with exceptionally high concentrations of monoterpenes as the squared correlation coefficient $\left(R^{2}\right)$ for the first peak was 0.79 , and 0.70 for the head of the second peak. An $R^{2}$ value of 0.80 has been obtained for the tailing part of the third peak. The head of this peak could not be analysed due to a gap in the monoterpene mixing ratio data. The $R^{2}$-value for the peak around 04:00 LT was 0.65. Minor peaks in the monoterpene mixing ratios during the second half of the night were not accompanied by peaks in the total particle number concentration.

The stratification of the nocturnal surface layer under investigation was apparent in the ambient temperature, humidity, wind speed and wind direction measured at SMEARII (see Fig. 10a and b). Even though ambient temperatures re-
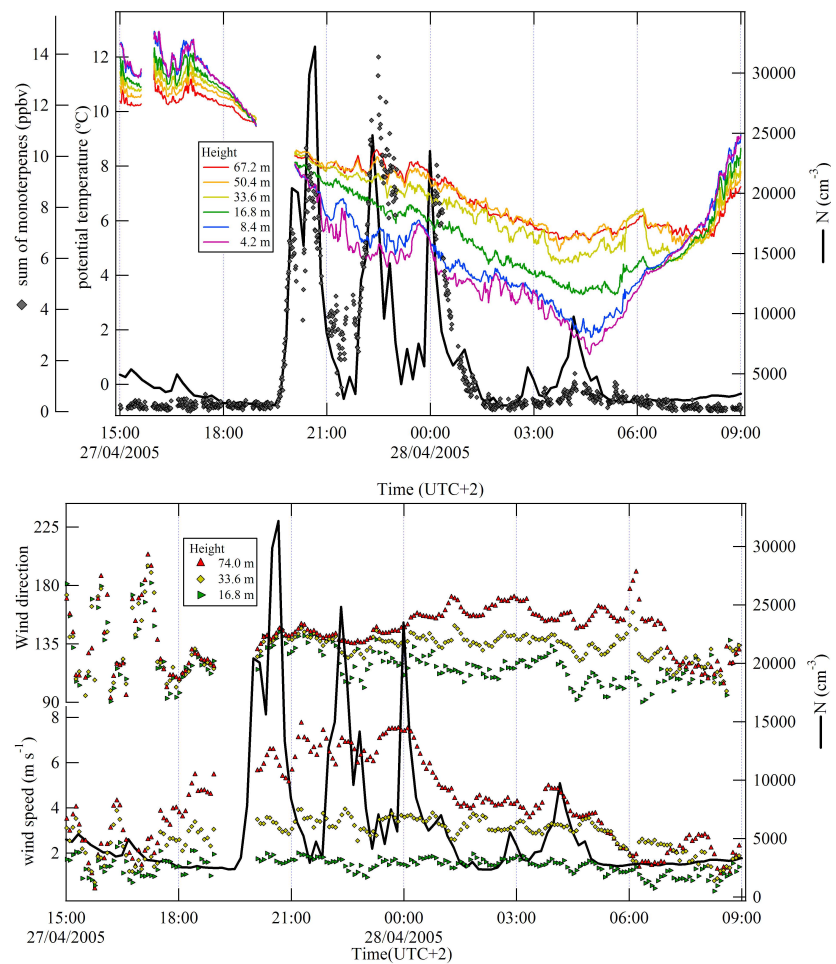

Fig. 10. Total aerosol number concentration (black solid lines) in relation to the potential temperature and monoterpenes (a) wind direction and wind speed (b), measured at SMEAR II during Event 2.

mained positive, they dropped by $9^{\circ} \mathrm{C}$ at $4.2 \mathrm{~m}$ and by $5^{\circ} \mathrm{C}$ at $67.2 \mathrm{~m}$ over the course of the night. The first particle burst of Event 2 occurred when the inversion was formed. In between the particle bursts, there were short gusts of somewhat warmer air interspersed with the cooling of the air within the canopy.

The wind blew fairly steadily from the South-East above $16.8 \mathrm{~m}$ over the course of Event 2. The angular deviation of the wind above the canopy with height became more apparent after midnight with deviations of $15-30^{\circ}$ between the different levels (Fig. 10b). Wind speeds below $33.6 \mathrm{~m}$ have been fairly constant throughout the night and were significantly different in between all levels. Average wind speeds were $0.6,1.6$, and $3.3 \mathrm{~m} / \mathrm{s}$ at $8.4 \mathrm{~m} 16.8 \mathrm{~m}$ and $33.6 \mathrm{~m}$, respectively.

In contrast to the other VOCs (discussed below) methane mixing ratios clearly increased from $1.78 \mathrm{ppmv}$ to $1.81 \mathrm{ppmv}$ at the onset of the NBL and remained above 1.79 ppmv for the rest of the night, only increasing again in the early morning to 1.8 ppmv (Fig. 11b).

The prevailing CO mixing ratios were $140-160 \mathrm{ppbv}$ (not shown). Due to a data recording failure, only the end of the peak in $\mathrm{CO}$ has been captured showing a drastic change by $\sim 50 \mathrm{ppbv}$ during the first part of the first burst in Event 2. 

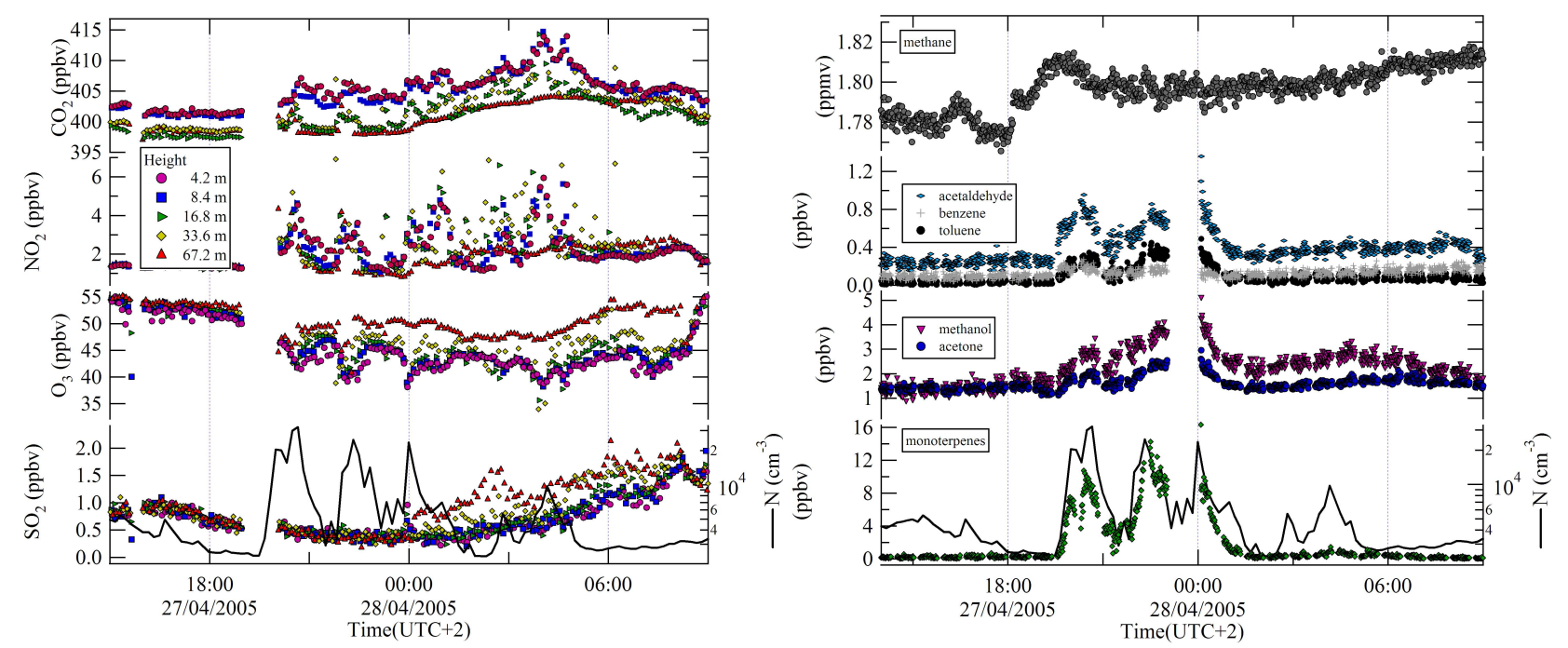

Fig. 11. (a) $\mathrm{CO}_{2}, \mathrm{O}_{3}, \mathrm{NO}_{2}, \mathrm{SO}_{2}$, and (b) $\mathrm{VOC}$ mixing ratios in relation to the aerosol particle total concentration for Event 2.

CO mixing ratios gradually increased from 160 to $180 \mathrm{ppbv}$ between 03:00 LT and 09:00 LT.

$\mathrm{SO}_{2}$ mixing ratios declined during the first 2 bursts of Event 2 strongly suggesting there it has no role in this event (Fig. 11a). Gradual but substantial increases in $\mathrm{SO}_{2}$ mixing ratios from $\sim 0.3 \mathrm{ppbv}$ up to $1.8 \mathrm{ppbv}$ at canopy level but most substantially above $30 \mathrm{~m}$ have been observed on all measurement levels after midnight (around the occurrence of the third peak), maximising at 09:00 LT.

Each particle burst was marked by exceptional increases in $\mathrm{CO}_{2}$ and $\mathrm{NO}_{\mathrm{x}}$ and drops in $\mathrm{O}_{3}$ on all measurement levels. Peaks in the $\mathrm{CO}_{2}$ mixing ratios extended well beyond the natural fluctuation. Similar peaks have also been observed on several occasions during this campaign together with peaks in monoterpenes, particles and $\mathrm{NO}_{2}$ and drops in $\mathrm{O}_{3}$. Between dusk and dawn, there was a clear vertical gradient in ozone with mixing ratios within the forest consistent with a surface or chemical loss. The gradient in ozone during Event 2 was as strong as 5-12 ppbv, much stronger than the gradient of less than 2 ppbv seen on nights without particle concentration increases. The highest peak in $\mathrm{NO}_{2}$ was observed coincidently with the peak in the particle concentration around 04:00 LT with $\mathrm{NO}_{2}$ mixing ratios up to $7.5 \mathrm{ppbv}$ within the canopy and occasionally spiking up to $14 \mathrm{ppbv}$ of $\mathrm{NO}_{\mathrm{x}}$ at the $33.6 \mathrm{~m}$ (off scale in Fig. 11a).

VOC mixing ratios generally were not well correlated with each other during this campaign with the exception of methanol, acetaldehyde and acetone, except during the night time events. Methanol, acetaldehyde and acetone are too volatile to take part in particle formation or growth but may be emitted directly or be formed as oxidation products. Biomass burning can be eliminated as a source as there was no substantial increase in acetonitrile during Event 2.
Strong increases in compounds like benzene, toluene, $\mathrm{C}_{2}$ and $\mathrm{C}_{3}$-benzenes during each peak of Event 2 points to fossil fuel combustion processes. The ratio [toluene]/[benzene] went up to 5, and was found to increase from the first to the third peak. The ratio was on average 2 between 19:30 and 01:00 and was calculated to be 0.5 for the rest of the night. Although toluene declined at daybreak, benzene increased until 09:00, similar to CO (discussed below). $R^{2}$ for Event 2 data for toluene and acetone was 0.74 . Acetone and toluene are known to be often emitted by anthropogenic sources.

Although there has not been additional proof from the TDGCMS measurements, we strongly believe that the increases in $m / z 69$ and $m / z 71$ during Event 2 were very unlikely related to natural emission of isoprene and its oxidation products given the time of the emissions and squared correlation coefficients for $\mathrm{m} / z, 71$ and $\mathrm{m} / \mathrm{z} 69$ with toluene $(\mathrm{m} / \mathrm{z}, 93)$ were 0.61 and 0.59 , respectively. Therefore it seems more likely that isobaric compounds or fragments of compounds at $\mathrm{m} / \mathrm{z} 87$ have caused the increase in the signal at $\mathrm{m} / \mathrm{z} 69$. Our measurements indicate that there has been a stronger contribution the second and third peak of Event 2 onto $m / z 69$ than to $m / z 87$ compared to the first peak in the series.

Without further identification we note that there have been synchronous increases in the signals at $m / z 73,75,83,95$, 117,141 but not at $m / z 77,85,105$. Figures 3 and 4 in Bonn et al. (2008b) show elevated pinonaldehyde mixing ratios between 25 and 29 April matching the elevated monoterpene mixing ratios presented here.

The overall contribution of carbonaceous compounds to the ambient air was about $100 \mathrm{ppbC}$ as measured by the total hydrocarbon analyser.

The RH of the air closer to the forest floor was higher than above and generally increased from dusk (18:00) to dawn 

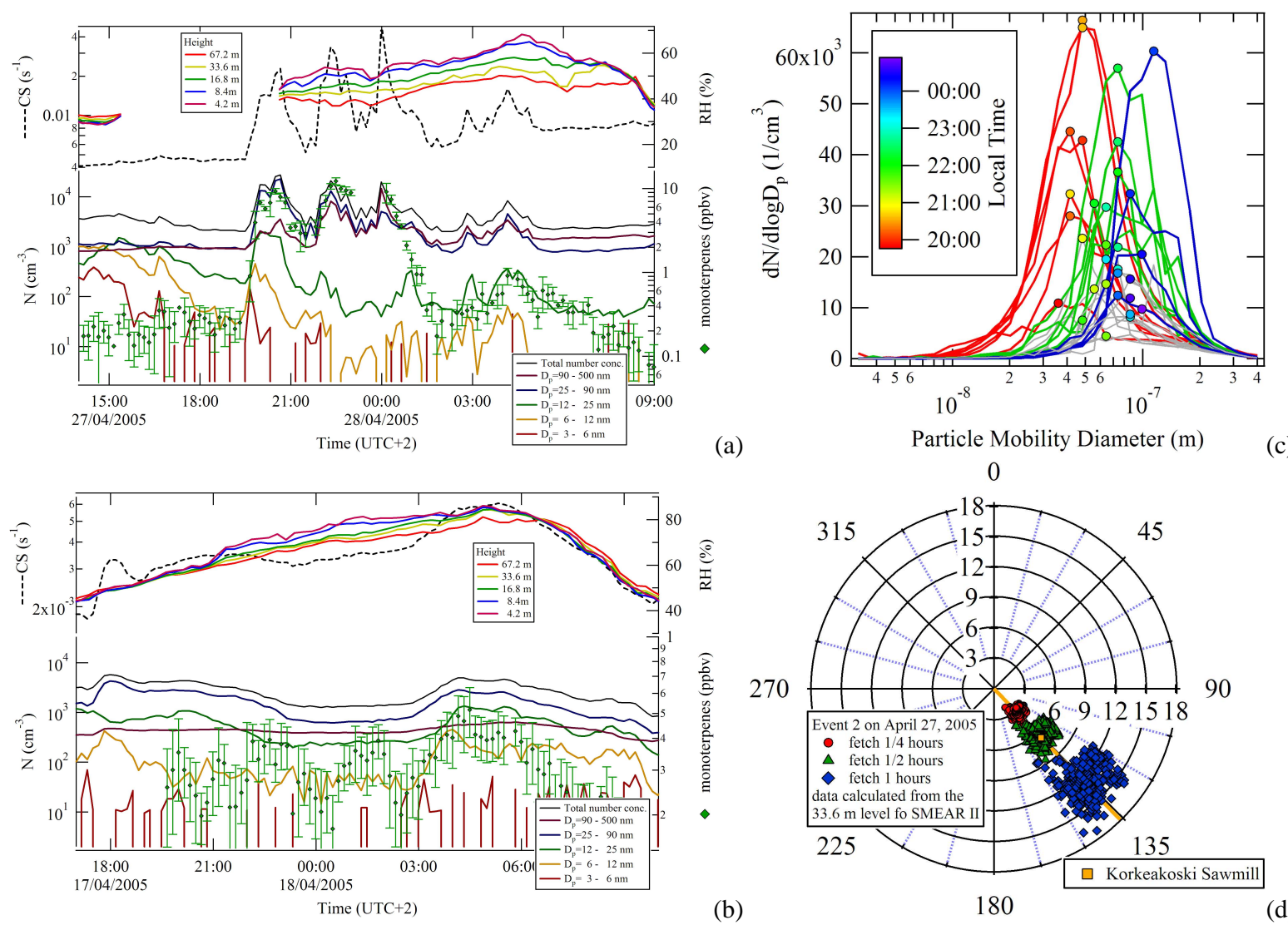

Fig. 12. RH, CS and monoterpenes mixing ratios ( $\pm 1 \sigma$ over the measurement interval of the DMPS) as function of time for (a) Event 2 and (b) the second selected nighttime event. (c) Particle size distribution for the 3 intense peaks of Event 2 in red, blue and green and (d) the corresponding 15, 30 and 60 min plain fetch calculated from the $33.6 \mathrm{~m}$ SMEAR II wind data in kilometres to the site. Highlighted is the direction in which the Korkeakoski saw mill is located.

(04:30) on all levels with a stronger rate of increase after midnight (Fig. 12a). The RH increased from 44 to 53\% before midnight and increased further to $68 \%$ at $04: 30$ at $4.2 \mathrm{~m}$ above the forest floor, whereas at $67.2 \mathrm{~m} \mathrm{RH}$ was around $39 \%$ before midnight and increased only to $50 \%$ just before sunrise.

In contrast to Event 1, small and large particles were present right from the beginning of the first burst of Event 2 suggesting that this was not a nucleation event. The condensational sink (typically examined for sulphuric acid, may serve as well for other molecules in a similar size range) for Event 2. It is shown in Fig. 12a and indicates very short lifetimes of molecules which have an affinity with particle surfaces. Peak values of CS were $0.023,0.034$ and $0.051 \mathrm{~s}^{-1}$ (corresponding to lifetimes of 43, 29 and barely $20 \mathrm{~s})$. Even for the fourth burst the lifetime was only $62 \mathrm{~s}$. Most vapours with low vapour pressure will probably end up on pre-existing aerosol particles.

4-day backward trajectories indicated that for Event 2, the air came from Central and Southern Finland between 26 and 28 April and show that the air mass has remained close to the surface $(>500 \mathrm{~m}$ ) for several days. The lifetime of e.g. $\alpha$ pinene with respect to ozone under the conditions of Event 2 was 16 to $22 \mathrm{~min}$. Empirical calculations, purely based on the measured wind speed and direction as measured at $16.8 \mathrm{~m}$, suggest that air parcels released 5, 30 and 60 min back in time would have covered a distance of approximately $\sim 2$ to $\sim 4 \mathrm{~km}, \sim 4$ to $\sim 6 \mathrm{~km}$, and $\sim 6$ to $\sim 14 \mathrm{~km}$ (see Fig. $12 \mathrm{~d}$ ).

At slightly more than $6 \mathrm{~km}$ distance and 136 degrees South-East of the SMEAR II station, the Korkeakoski sawmill is located in the town Juupajoki (the yellow square in Fig. 12d represents the location of the Korkeakoski sawmill relative to the SMEAR II observatory at the origin). This sawmill has an annual production capacity of 330000 cubic metres of softwood products, notably for the joinery industry and in this respect a very plausible source of the massive monoterpene emissions and other associated pollutants. However, intensive forest management activities carried out in the same section upwind of SMEAR II may also qualify.

Additional support for this source identification was obtained from the detailed analyses of the monoterpenes by TD-GC-MS which includes an enantiomeric separation. It 


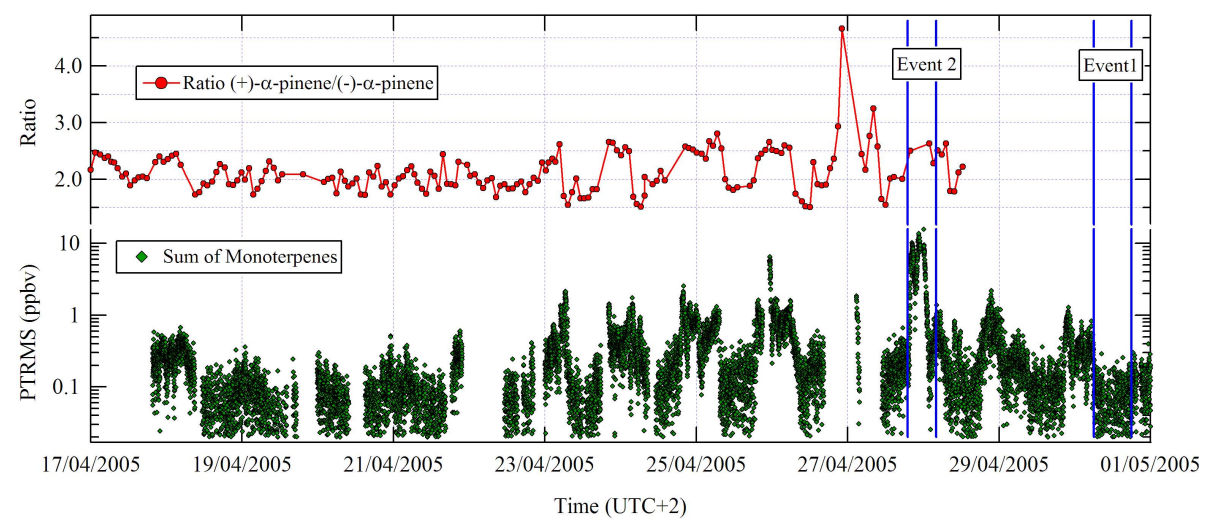

Fig. 13. Enantiomeric ratio of (+)- $\alpha$-pinene to (-)- $\alpha$-pinene as function of time in connection to the sum of all monoterpenes for the entire period of investigation.

has been shown previously that (+)- $\alpha$-pinene, $(+)-\delta$-3-carene, $(-)-\alpha$-pinene and (-)- $\beta$-pinene were the most abundant monoterpenes above the boreal forest. This monoterpene composition resembles that found in the emission of $P$. sylvestris with low (+)- $\delta$-3-carene chemotype in the branch enclosure cuvette study (Yassaa and Williams, 2007). Figure 13 shows that daytime enantiomeric ratios of $[(+)-\alpha-$ pinene $] /[(-)-\alpha$-pinene $]$ varied between 1.6 and 2 and that the night time ratio was usually higher $(\sim 2.5)$. There have been several occasions during this campaign for which the enantiomeric ratio was significantly higher (3-5). Such significantly higher peaks on 26 and 27 April were believed to be of a similar kind as monitored by the PTR-MS during Event 2, during which the GCMS was being calibrated. Subsequent study of the enantiomeric composition of monoterpenes from intact and damaged or wounded Scots pine has been conducted with solid-phase microextraction (SPME) combined with dynamic branch enclosure cuvettes and enantioselective GC-MS. The detached needles from P. sylvetsris, the dominant forest species, exhibited different enantiomeric emission patterns for the most abundant chiral monoterpene $\alpha$ pinene. Damaging the plants seems to induce modifications not only to the emission rate of monoterpenes but also on their enantiomeric compositions. In the wounded plant materials, while the emission rates of monoterpenes increase by several orders of magnitude, the $[(+)-\alpha$-pinene/(-)- $\alpha-$ pinene] enantiomeric ratios pass from $\sim 2$ for intact plants to $\sim 6$ for damaged trees, similarly to what was observed in the Event 2. Therefore, the substantial increase in the mixing ratios of monoterpenes together with the $[(+)-\alpha$-pinene/(-)$\alpha$-pinene] enantiomeric ratios observed during the Event 2 strongly supports the hypothesis that the wood industry is the very likely source of monoterpenes during the Event 2 and according to this line of reasoning also be responsible for all increased levels of monoterpenes.

To support our analysis and to summarise the conditions typical for these night time events, a second, less intense night time event has been selected. Nine days prior to Event 2 (on 18 April, about 03:00 LT) generally showing the main characteristics of Event 2. The nocturnal surface layer had been stratified expressed by a potential gradient reaching $0.05 \mathrm{~K} / \mathrm{m}$ as well as a strong gradient in the relative humidity (here up to $8 \%$ ) with the air near the forest floor being more moist. Ambient air temperatures on all measurement levels declined to $-2^{\circ} \mathrm{C}$ around 06:00 LT and were about $0^{\circ} \mathrm{C}$ at the start of the event. The wind speeds were very constant and distinct at the different levels $(2.0 \pm 0.4 \mathrm{~m} / \mathrm{s}, 3.6$ $\pm 0.4 \mathrm{~m} / \mathrm{s}$ and $6.6 \pm 0.4 \mathrm{~m} / \mathrm{s}$ at $16.8 \mathrm{~m}, 33.6 \mathrm{~m}$ and $74.0 \mathrm{~m}$ respectively). Only this time, the wind blew northeast at $74 \mathrm{~m}$ just after the onset of the NBL and veered to north northeast over the course of the night. Wind directions measured below deviated again by $10^{\circ}-15^{\circ}$ and indicate the stratification. This figure also shows the positive correlation between the monoterpenes mixing ratio (maximising around $0.6 \mathrm{ppbv}$ at $04: 15 \mathrm{LT}$ ) and the particle number concentrations (total $\sim 4900 \mathrm{~cm}^{-3}$ ). Important to note is that this event involves particle formation characterised by a shift in particle size and an increase in number concentration over the course of time.

This night time event is characterised by similar changes in monoterpenes and other trace gases as discussed previously. Peaks in the monoterpene mixing ratios match peaks in the $\mathrm{CO}_{2}\left(\Delta \mathrm{CO}_{2}: 2-4 \mathrm{ppmv}\right)$ on top of the natural respiration profile (increase $395-405 \mathrm{ppmv}$ at $8.4 \mathrm{~m}$ over the course of the night). They correspond to simultaneous drops in ozone $\left(\Delta \mathrm{O}_{3}: 2-7 \mathrm{ppbv}\right)$ on top of the nocturnal decline in ozone from 40 to $30 \mathrm{ppbv}$. NO mixing ratios were low $(<0.1 \mathrm{ppbv})$ but $\mathrm{NO}_{2}$ mixing ratios increased $3 \mathrm{~h}$ prior to the night time event up to $1.2 \mathrm{ppbv}$ at $4.2 \mathrm{~m}$ and $2.5 \mathrm{ppbv}$ at $74 \mathrm{~m}$ at 09:00 LT. A similar change over the course of time has been found for $\mathrm{SO}_{2}$. Mixing ratios increased from 0.5 to $1.8 \mathrm{ppbv}$ at $4.2 \mathrm{~m}$ and even stronger increases at the top level 0.7-2.5 ppbv, maximising at 09:00 LT. Elevated levels of $\mathrm{SO}_{2}$ were only observed during the second part of the night of 28 April, not during the most intense bursts in particles and in 
monoterpenes. The ratio of $[(+)-\alpha$-pinene $] /[(-)-\alpha$-pinene $]$ was 2.3-2.5 during the night of 18 April corresponding to damaged needles as observed during Event 2.

\section{Discussion and conclusions}

Rural background mixing ratios for the boreal forest have been determined for several VOCs during the transitional period between winter and spring when air masses come from the North crossing Finland. Most of the analysed non methane hydrocarbons in this generally clean air did not show distinct diel profiles. Of the VOCs measured, methanol, acetone and acetaldehyde were the most abundant daytime organic species present. The biogenic VOCs observed during this study predominantly result from coniferous trees as the deciduous trees were still leafless at this time of the year.

Elevated levels of anthropogenic pollutants were observed typically in the morning and the evening, presumably by commuter traffic or on occasions when air masses had passed over urbanized areas, marked by e.g. peaks in $\mathrm{NO}_{2}$ and $\mathrm{SO}_{2}$.

Elevated levels of monoterpenes were observed during night time presumably through the formation of a shallow nocturnal inversion layer at night over the continuously emitting vegetation. However, the levels were sometimes too high to be explained by this effect alone and are possibly supplemented by emissions into the NBL by forest management activities.

In this study, a daytime and a night-time aerosol event exhibiting high particle concentrations, were analysed using the available meteorological, organic and inorganic trace gases measurements. Figure 6 shows that Event 1 (daytime; 30 April) was characterised by a fivefold increase in the total aerosol concentration $(\mathrm{N})$ lasting several hours and Event 2 (night-time; 27-28 April) was of short duration with 11 fold increase in $\mathrm{N}$.

Event 1 is characterised by an abrupt start with clear particle growth starting above the smallest size classes. We have shown that the occurrence of the event was very sensitive to the wind direction. We believe that the location of the edges of air masses qualify whether a particular day at SMEAR II can be archived as event day or non-event day.

Event 1 is characterised by an anti correlation of particle growth with sulphuric acid during nucleation. $\mathrm{H}_{2} \mathrm{SO}_{4}$ is known as the most important key player atmospheric new particle formation which is generally thought to occur due to homogeneous or ion-induced nucleation of sulphuric acid (Kulmala, 2003; Lovejoy et al., 2004). Recently, Laaksonen et al. (2008) and Berndt et al. (2008) suggested a new particle formation mechanism in which the free $\mathrm{HSO}_{5}$ radicals are formed prior to the $\mathrm{H}_{2} \mathrm{SO}_{4}$ formation. They suggest that at temperatures above $250 \mathrm{~K}$ these radicals produce nuclei of new aerosols much more efficiently than $\mathrm{H}_{2} \mathrm{SO}_{4}$ as well as that the $\mathrm{HSO}_{5}$ radicals will react with other trace species, and that the resulting molecules act as nuclei for heterogeneous nucleation of $\mathrm{H}_{2} \mathrm{SO}_{4}$ vapour which will initiate the growth of the new particles. Recently Kulmala et al. (2006) suggested that activation of existing clusters might be the actual atmospheric nucleation mechanism. The existence of those clusters has later been shown (Kulmala et al. 2007). On the other hand, a study by Väkeva et al. (2000) indicated that somewhat larger deviations in the wind direction may interrupt the conditions favourable for the growth of particles which might have been also the case for Event 1 . However, the growth of the particles by this mechanism may have been interrupted, by a reduced number of $\mathrm{HSO}_{5}$ radicals formed after the sudden overcast, with a clear relapse in the concentration of $\mathrm{H}_{2} \mathrm{SO}_{4}$.

The event was found to be sensitive to changes humidity for instance due to the appearance of clouds. The latter reduces the instantaneous production of $\mathrm{H}_{2} \mathrm{SO}_{4}$ via OH (reduced gas-phase oxidation chemistry) but also enhances the water content in the air (increase of the condensation sink of condensable gases due to hygroscopic growth of pre-existing particles). It has been observed in different continental locations that nucleation events take preferentially place at low relative humidity (e.g. Hamed et al., 2007; Hyvönen et al., 2005; Laaksonen et al., 2008b) as a higher humidity implements a larger possibility of enhanced coagulation of sub $3 \mathrm{~nm}$ clusters.

From all nucleation events arising during this campaign, we conclude that there is a certain condition upon which nucleation occurs and the strength of a nucleation event is not equivalent to the locally measured mixing ratio of $\mathrm{H}_{2} \mathrm{SO}_{4}$. This could possibly be explained by the competition between the growth of freshly formed particles and their loss by scavenging, rather than a limit in the initial particle production by nucleation of sulphuric acid (Riipinen et al., 2007).

No evidence was found that monoterpenes or other volatile organic compounds measured during this campaign were involved in the growth of particles during nucleation Event 1. Future work should include measuring condensable organics e.g. oxidation products of all terpenes.

In contrast, particle Event 2 is characterised by a very clear correlation with monoterpenes and no correlation with sulphuric acid. During Event 2, sulphuric acid concentrations were found to be relatively low and $\mathrm{SO}_{2}$ mixing ratios declined during the intensive night-time bursts in aerosol particles before midnight. The source was characterised as releasing more toluene relative to benzene; more methanol relative to acetone; and above all, releasing massive amounts of aerosol particles, $\mathrm{CO}_{2}$, monoterpenes and $\mathrm{NO}_{2}$. The latter two are known to be very reactive towards ozone explaining the drops in the ozone mixing ratios.

Here we suggest the wood industry as the likely source. Monoterpenes and many other VOCs may have come directly from the cut wood whereas the $\mathrm{NO}_{\mathrm{x}}$ and BTEX compounds come from the generators/cutting tools used. Recently Junninen et al., 2008 investigated night-time particle 
production events. Typically strong night particle production in Aitken and accumulation modes was connected to local pollution.

A study by Schade and Goldstein, (2003) also reported 10fold increases of monoterpene emissions from a pine plantation as a result of mechanical disturbances. During the period of measurements we noted some deforestation activities nearby, to the south west of the measurement location and although we did not notice any burning during the campaign. Thinning is a routine forest management operation that changes tree spacing, number, and size distribution which can affect the emission of VOCs from vegetation to the atmosphere. A study by Vesala et al. (2005) has shown some effects of thinning on physical processes like wind speed normalized by the friction velocity, light penetration, and particle deposition. Some of these forest management activities undoubtedly can have implications for regional air quality management, likely both in terms of ozone chemistry and secondary aerosol formation (Goldstein et al., 2004). However, in this case the strong dependence on the wind direction strongly suggests that the sawmill was the source of these bursts.

It is well established that secondary aerosol particles can be formed during monoterpene oxidation, but is this process sufficient enough to deliver more than 20000 particles $/ \mathrm{cm}^{3}$ in half an hour under atmospheric conditions? The second night time event addressed did not involve such enormous particle concentrations but it has been characterised by nucleation.

To begin with, nucleation in the monoterpene/ozone system could not be explained by classical nucleation theory involving sulphuric acid. According to Bonn et al. (2007) it involves 1) the formation of nucleation inducing molecules; 2) the activation and initial growth by reactive trace gases such as $\mathrm{RO}_{2} ; 3$ ) above about $3 \mathrm{~nm}$ in diameter condensation of oxidised compounds such as acids, nitrates, hydroperoxides etc provide for further growth.

Primary ozonides of monoterpenes are formed first which then decompose into Criegee biradical and carbonyl compounds as discussed in e.g. Koch et al. (2000). The carboxylic acids which can be formed from the Criegee biradical will have a lower yield over the carbonyl compounds (Calogirou et al., 1999). Bonn and Moortgat (2002) following the reaction of $\alpha$ - and $\beta$-pinene with ozone (each $500 \mathrm{ppbv}$ ) observed various products of different volatility non-, semi- and volatiles. The non-volatile products reached their saturation vapour pressure and started to nucleate homogeneously. This was observed during the ozonolysis reaction in an intense nucleation during the first four minutes of the experiment. At this stage of the reaction, the more volatile products (semi-volatile) were able to condense on the surface of the pre-formed particles and cause an increase in particle size and aerosol volume. This behaviour was observed in a broadening, and a shift of the particle size distribution to larger diameters (centred around $60 \mathrm{~nm}$ in di- ameter at $50 \mathrm{~min}$ reaction time) due to both the coagulation as well as the condensation. The authors measured a $\mathrm{N}$ of $10^{6}$ particles $/ \mathrm{cm}^{3}$ distributed around $20 \mathrm{~nm}$ after $4 \mathrm{~min}$, and $7.10^{5}$ particles $/ \mathrm{cm}^{3}$ distributed around $60 \mathrm{~nm}$ after $12 \mathrm{~min}$. However, under ambient conditions as in Koch et al. (2000) and Bonn and Moortgat, (2003), the nucleation threshold was found to be $\sim 2 \mathrm{ppbv}$ of monoterpenes but the calculated atmospheric nucleation time eliminates the possibility of nucleation by reaction of monoterpenes with ozone. This however becomes possible if sesquiterpenes were to be involved which is very well possible but cannot be proven here by measurements. Sesquiterpenes are much more reactive than monoterpenes and the nucleation threshold and the atmospheric nucleation time is much lower. 2.5 pptv of sesquiterpenes could be exceeded in Hyytiälä in less than 3 min (Hakola et al., 2000).

Signatures of the sawmill have not always been as intense as during the nights of 25 to 29 of April. Accepting a threshold of $2.4(1 \sigma)$ for the ratio of $[(+)-\alpha$-pinene $] /[(-)-\alpha$-pinene $]$ results in 8 out of 14 days of measurements for which the ratio has been above 2.4 . It is very well possible that even more sesquiterpenes are emitted during forestry activities than under natural conditions leading to atmospheric biogenic SOA which in a later stage (for example during transport to the site) can grow by compounds arising from monoterpenes ozonolysis. This could possibly explain the similarity in the observed size distribution from Event 2 with those from the laboratory experiment of Bonn and Moortgat, (2002).

We may conclude from this study that Event 1 (30 April) is typical nucleation event and Event 2 (27 April) is a pollution episode. However, we have shown that new particle formation can occur at night under similar conditions as Event 2 (e.g. 18 April). Forestry activities and the sawmill industry can under certain meteorological circumstances substantially influence air chemistry and the aerosol burden over Hyytiälä, especially under stable meteorological conditions.

For future studies, it would be advisable to perform high resolution observations of mono- and sesquiterpenes and their oxidation products in combination with measurement on the physico-chemical characteristics of aerosol particles and boundary layer meteorological measurements over boreal forests to better constrain the role of organics in daytime and night time new particle formation.

Acknowledgements. We acknowledge the support from the staff of the Hyytiälä field forest station as well as by all the collaborating partners within the BACCI and QUEST projects. We thank Boris Bonn for helpful discussions. The Max Planck Society and ACCENT are kindly acknowledged for financial support.

The service charges for this open access publication have been covered by the Max Planck Society.

Edited by: T. Karl 


\section{References}

Aalto, P. P., Hämeri, K., Becker, E., Waber, R., Salm, J., Mäkelä, J., Hoell, C., O’Dowd, C. D., Karlsson, H., Hansson, H., Väkevä, M., Koponen, I. K., Buzorius, G., and Kulmala, M.: Physical characterization of aerosol particles during nucleation events, Tellus 53B, 344-358, 2001.

Anttila, P., Rissanen, T., Shimmo, M., Kallio, M., Hyotylainen, T., Kulmala, M., and Riekkola, M. L.: Organic compounds in atmospheric aerosols from a Finnish coniferous forest, Bor. Environ. Res., 10, 371-384, 2005.

Bäck, J., Hari, P., Hakola, H., Juurola, E., and Kulmala, M.: Dynamics of monoterpene emissions in Pinus sylvestris during early spring, Bor. Eniviron. Res., 10 409-424, 2005.

Berndt, T., Stratmann, F., Bräsel, S., Heintzenberg, J., Laaksonen, A., and Kulmala, M.: $\mathrm{SO}_{2}$ oxidation products other than $\mathrm{H}_{2} \mathrm{SO}_{4}$ as a trigger of new particle formation - Part 1: Laboratory investigations, Atmos. Chem. Phys., 8, 6365-6374, 2008,

http://www.atmos-chem-phys.net/8/6365/2008/.

Birmili, W., Berresheim, H., Plass-Dülmer, C., Elste, T., Gilge, S., Wiedensohler, A., and Uhrner, U.: The Hohenpeissenberg aerosol formation experiment (HAFEX): a long-term study including size-resolved aerosol, $\mathrm{H}_{2} \mathrm{SO}_{4}, \mathrm{OH}$, and monoterpenes measurements., Atmos. Chem. Phys., 3, 361-376, 2002,

http://www.atmos-chem-phys.net/3/361/2002/.

Blake, R. S., Monks, P. S., and Ellis, A. M.: Proton-Transfer Reaction Mass Spectrometry, Chemical Reviews, 109, 861-896, doi:10.1021/cr800364q, 2009.

Bonn, B. and Moortgat, G. K.: New particle formation during $\alpha$ and $\mathrm{B}$-pinene oxidation by $\mathrm{O}_{3}, \mathrm{OH}$ and $\mathrm{NO}_{3}$, and the influence of water vapour: particle size distribution studies, Atmos. Chem. Phys., 2, 183-196, 2002,

http://www.atmos-chem-phys.net/2/183/2002/.

Bonn, B. and Moortgat, G. K.: Sesquiterpene ozonolysis: Origin of atmospheric new particle formation from biogenic hydrocarbons, Geophys. Res. Lett., 30(4), 1585, doi10.1029/2003g1017000, 2003.

Bonn, B., Korhonen, H., Petäjä, T., Boy, M., and Kulmala, M.: Understanding the formation of biogenic secondary organic aerosol from alpha-pinene in smog chamber studies: role of organic peroxy radicals., Atmos. Chem. Phys. Discuss., 7, 3901-3939, 2007 ,

http://www.atmos-chem-phys-discuss.net/7/3901/2007/.

Bonn, B., Boy, M., Dal Maso, M., Hakola, H., Hirsikko, A., Kulmala, M., Kurtén, T., Laakso, L., Mäkelä, J., Riipinen, I., Rannik, Ü., Sihto, S.-L., and Ruuskanen, T. M.: Biogenic Sesquiterpenes and Atmospheric New Particle Formation: A Boreal Forest Site Investigation, Nucleation and Atmospheric Aerosols; 17th International Conference, Galway, Ireland 2007, 344-349, 2008a.

Bonn, B., Kulmala, M., Riipinen, I., Sihto, S.-L., and Ruuskanen, T. M.: How biogenic terpenes govern the correlation between sulfuric acid concentrations and new particle formation, J. Geophys. Res., 113, D12209, doi:10.1029/2007JD009327, 2008 b.

Calogirou, A., Larsen, B. R., and Kotzias, D.: Gas phase terpene oxidation products: A review, Atmos. Environ.t, 33A, 1352-2310, 1999.

Dal Maso, M., Kulmala, M., Riipinen, I., Wagner, R., and Hussein, T.: Formation and growth of fresh atmospheric aerosols: eight years of aerosol size distribution data from SMEAR II, Hyytiälä, Finland, Bor. Environ. Res., 10, 323-336, 2005.
Eerdekens, G., Ganzeveld, L., Vilà-Guerau de Arellano, J., Klüpfel, T., Yassaa, N., Williams, J., Harder, H., Kubistin, D., Martinez, M., and Lelieveld, J.: Isoprene, methanol and acetone flux estimates from airborne PTRMS measurements over above the tropical rainforest during the GABRIEL 2005 campaign., Atmos. Chem. Phys., 9, 4207-4227, 2009,

http://www.atmos-chem-phys.net/9/4207/2009/.

Fiedler, V., Dal Maso, M., Boy, M., Aufmhoff, H., Hoffmann, J., Schuck, T., Birmili, W., Hanke, M., Uecker, J., Arnold, F., and Kulmala, M.: The contribution of sulphuric acid to atmospheric particle formation and growth: a comparison between boundary layers in Northern and Central Europe, Atmos. Chem. Phys., 5, 1773-1785, 2005, http://www.atmos-chem-phys.net/5/1773/2005/.

Goldstein, A. H., McKay, M., Kurpius, M. R., Schade, G. W., Lee, A., Holzinger, R., and Rasmussen, R. A.: Forest thinning experiment confirms ozone deposition to forest canopy is dominated by reaction with biogenic VOCs, Geophys. Res. Lett., 31, L22106, doi:10.1029/2004GL021259, 2004.

Haapanala, S., Rinne, J., Hakola, H., Hellén, H., Laakso, L., Lihavainen, H., Janson, R., O'Dowd, C., and Kulmala, M.: Boundary layer concentrations and landscape scale emissions of volatile organic compounds in early spring, Atmos. Chem. Phys., 7, 1869-1878, 2007, http://www.atmos-chem-phys.net/7/1869/2007/.

Hakola, H., Laurina, T., Rinne, J., and Puhto, K.: The ambient concentrations of biogenic hydrocarbons at a northern European, boreal site, Atmos. Environ., 34, 4971-4982, 2000.

Hakola, H., Tarvainen, V., Laurila, T., Hiltunen, V., Hellen, H., and Keronen, P.: Seasonal variation of VOC concentrations above a boreal coniferous forest, Atmos. Environ., 37, 1623-1634, 2003.

Hamed, A., Joutsensaari, J., Mikkonen, S., Sogacheva, L., Dal Maso, M., Kulmala, M., Cavalli, F., Fuzzi, S., Facchini, M. C., Decesari, S., Mircea, M., Lehtinen, K. E. J., and Laaksonen, A.: Nucleation and growth of new particles in Po Valley, Italy, Atmos. Chem. Phys., 7, 355-376, 2007, http://www.atmos-chem-phys.net/7/355/2007/.

Hanke, M., Uecker, J., Reiner, T., and Arnold, F.: Atmospheric peroxy radicals: ROXMAS, a new mass-spectrometric methodology for speciated measurements of $\mathrm{HO}_{2}$ and $\mathrm{Sigma} \mathrm{RO}_{2}$ and first results, Int. J. Mass Spectrom., 213, 91-99, 2002.

Hari, P. and Kulmala, M.: Station for Measuring EcosystemAtmosphere Relations (SMEAR II), Bor. Environ. Res., 10, 315322, 2005.

Hellén, H., Hakola, H., Reissell, A., and Ruuskanen, T. M.: Carbonyl compounds in boreal coniferous forest air in Hyytiälä, Southern Finland, Atmos. Chem. Phys., 4, 1771-1780, 2004, http://www.atmos-chem-phys.net/4/1771/2004/.

Helmig, D., Greenberg, J., Guenther, A., Zimmerman, P., and Geron, C.: Volatile organic compounds and isoprene oxidation products at a temperate deciduous forest site, J. Geophys. Res.Atmos., 103, 22397-22414, 1998.

Hyvönen, S., Junninen, H., Laakso, L., Dal Maso, M., Gronholm, T., Bonn, B., Keronen, P., Aalto, P., Hiltunen, V., Pohja, T., Launiainen, S., Hari, P., Mannila, H., and Kulmala, M.: A look at aerosol formation using data mining techniques, Atmos. Chem. Phys., 5, 3345-3356, 2005,

http://www.atmos-chem-phys.net/5/3345/2005/.

Janson, R.: Monoterpene concentrations in and above a forest of 
Scots pine, J. Atmos. Chem., 14, 385-394, 1992.

Janson, R., and De Serves, C.: Emissions of Biogenic VOCs from Boreal Ecosystems, in: Biogenic VOC emissions and photochemistry in the boreal regions of Europe - Biphorep, edited by: Lindfors, T. L. a. V., European Commission, 45-56, 1999.

Janson, R. and De Serves, C.: Acetone and monoterpene emissions from the boreal forest in northern Europe, Atmos. Environ., 35, 4629-4637, 2001.

Junninen, H., Hulkkonen, M., Riipinen, I., Nieminen, T., Hirsikko, A., Suni, T., Boy, M., Lee, S.-H., Vana, M., Tammet, H., Kerminen, V.-M., and Kulmala, M.: Observations on nocturnal growth of atmospheric clusters, Tellus 60B, 365-371, 2008.

Koch, S., Winterhalter, R., Uherek, E., Kolloff, A., Neeb, P., and Moortgat, G. K.: Formation of new particles in the gas-phase ozonolysis of monoterpenes, Atmos. Environ.t, 34, 4031-4042, 2000.

Kulmala, M., Dal Maso, M., Mäkelä, J. M., Pirjola, L., Väkevä, M., and Aalto, P. P.: On the formation, growth and composition of nucleation mode particles, Tellus, 53B, 479-490, 2001a.

Kulmala, M., Hämeri, K. K., Aalto, P., Mäkelä, J., Pirjola, L., Nilsson, E. D., Buzorius, G., Rannik, Ü., Dal Maso, M., Seidl, W., Hoffmann, T., Jansson, R., Hansson, H.-C., O’Dowd, C., and Viisanen, Y.: Overview of the international project on biogenic aerosol formation in the boreal forest (BIOFOR), Tellus B, 53, 324-342, 2001b.

Kulmala, M.: How particles nucleate and grow, Science, 302, 10001001, 2003.

Kulmala, M., Vehkamäki, H., Petäjä, T., Dal Maso, M., Lauri, A., Kerminen, V.-M., Birmili, W., and McMurry, P. H.: Formation and growth rates of ultrafine atmospheric particles: A review of observations, J. Aerosol Sci., 35, 143-176, 2004.

Kulmala, M., Lehtinen, K. E. J., and Laaksonen, A.: Cluster activation theory as an explanation of the linear dependence between formation rate of $3 \mathrm{~nm}$ particles and sulphuric acid concentration, Atmos. Chem. Phys., 6, 787-793, 2006, http://www.atmos-chem-phys.net/6/787/2006/.

Kulmala, M., Riipinen, I., Sipilä, M., Manninen, H. E., Petäjä, T., Junninen, H., Dal Maso, M., Mordas, G., Mirme, A., Vana, M., Hirsikko, A., Laakso, L., Harrison, R. M., Hanson, I., Leung, C., Lehtinen, K. E. J., and Kerminen, V.-M.: Toward direct measurement of atmospheric nucleation, Science, 318, 89-92, doi:10.1126/science.1144124, 2007.

Kulmala, M. and Kerminen, V.-M.: On the formation and growth of atmospheric nanoparticles, Atmos. Res., 90, 132-150, doi:10.1016/j.atmosres.2008.01.005, 2008.

Kurten, T., Kulmala, M., Dal Maso, M., Suni, T., Reissell, A., Vehkamäki, H., Hari, P., Laaksonen, A., Viisanen, Y., and Vesala, T.: Estimations of different forest-related contributions to the radiative balance using observations in Southern Finland, Bor. Environ. Res., 8, 275-285, 2003.

Laaksonen, A., Kulmala, M., Berndt, T., Stratmann, F., Mikkonen, S., Ruuskanen, A., Lehtinen, K. E. J., Dal Maso, M., Aalto, P. P., Petäjä, T., Riipinen, I., Sihto, S.-L., Janson, R., Arnold, F., Hanke, M., Ücker, J., Umann, B., Sellegri, K., O’Dowd, C. D., and Viisanen, Y.: $\mathrm{SO}_{2}$ oxidation products other than $\mathrm{H}_{2} \mathrm{SO}_{4}$ as a trigger of new particle formation - Part 2: Comparison of ambient and laboratory measurements, and atmospheric implications, Atmos. Chem. Phys., 8, 7255-7264, 2008a,

http://www.atmos-chem-phys.net/8/7255/2008/.
Laaksonen, A., Kulmala, M., O’Dowd, C. D., Joutsensaari, J., Vaattovaara, P., Mikkonen, S., Lehtinen, K. E. J., Sogacheva, L., Dal Maso, M., Aalto, P., Petaja, T., Sogachev, A., Yoon, Y. J., Lihavainen, H., Nilsson, D., Facchini, M. C., Cavalli, F., Fuzzi, S., Hoffmann, T., Arnold, F., Hanke, M., Sellegri, K., Umann, B., Junkermann, W., Coe, H., Allan, J. D., Alfarra, M. R., Worsnop, D. R., Riekkola, M. L., Hyotylainen, T., and Viisanen, Y.: The role of VOC oxidation products in continental new particle formation, Atmos. Chem. Phys., 8, 2657-2665, 2008b,

http://www.atmos-chem-phys.net/8/2657/2008/.

Lee, S. H., Young, L. H., Benson, D. R., Suni, T., Kulmala, M., Junninen, H., Campos, T. L., Rogers, D. C., and Jensen, J.: Observations of nighttime new particle formation in the troposphere, J. Geophys. Res.-Atmos., 113(7), D10210, doi:10.1029/2007jd009351, 2008.

Lovejoy, E. R., Curtius, J., and Froyd, K. D.: Atmospheric ioninduced nucleation of sulphuric acid and water, J. Geophys. Res., 109, D08204, doi:10.1029/2003JD004460, 2004.

Marti, J. J., Weber, R. J., McMurry, P. H., Eisele, F. L., Tanner, D. J., and Jefferson, A.: New particle formation at a remote continental site: Assessing the contributions of $\mathrm{SO}_{2}$ and organic precursors, J. Geophys. Res., 102, 6331-6339, 1997.

O’Dowd, C. D., Hameri, K., Makela, J., Vakeva, M., Aalto, P. P., de Leeuw, G., Kunz, G. J., Becker, E., Hansson, H. C., Allen, A. G., Harrison, R. M., Berresheim, H., Geever, M., Jennings, S. G., and Kulmala, M.: Coastal new particle formation: Environmental conditions and aerosol physicochemical characteristics during nucleation bursts, J. Geophys. Res.-Atmos., 107(17), 8107, doi:10.1029/2000jd000206, 2002.

Raes, F., Van Dingenen, R., Cuevas, E., VanVelthoven, P. F. J., and Prospero, J. M.: Observations of aerosols in the free troposphere and marine boundary layer of the subtropical Northeast Atlantic: Discussion of processes determining their size distribution, J. Geophys. Res.-Atmos., 102, 21315-21328, 1997.

Räisänen, T., Ryyppö, A., and Kellomäki, S.: Monoterpene emission of a boreal Scots pine (Pinus sylvestris L.) forest, Agr. For. Meteor., 149, 808-819, 2009.

Riipinen, I., Sihto, S.-L., Kulmala, M., Arnold, F., Dal Maso, M., Birmili, W., Saarnio, K., Teinilä, K., Kerminen, V.-M., Laaksonen, A., and Lehtinen, K. E. J.: Connections between atmospheric sulphuric acid and new particle formation during QUEST III-IV campaigns in Heidelberg and Hyytiälä, Atmos. Chem. Phys., 7, 1899-1914, 2007, http://www.atmos-chem-phys.net/7/1899/2007/.

Rinne, J., Ruuskanen, T. M., Reissell, A., Taipale, R., Hakola, H., and Kulmala, M.: On-line PTR-MS measurements of atmospheric concentrations of volatile organic compounds in a European boreal forest ecosystem, Bor. Environ. Res., 10, 425-436, 2005.

Ruuskanen, T. M., Taipale, R., Rinne, J., Kajos, M. K., Hakola, H., and Kulmala, M.: Quantitative long-term measurements of VOC concentrations by PTR-MS: annual cycle at a boreal forest site, Atmos. Chem. Phys. Discuss., 9, 81-134, 2009, http://www.atmos-chem-phys-discuss.net/9/81/2009/.

Schade, G. W. and Goldstein, A. H.: Increase of monoterpene emissions from a pine plantation as a result of mechanical disturbances, Geophys. Res. Lett., 30, 1380, doi:10.1029/2002GL016138, 2003.

Sellegri, K., Umann, B., Hanke, M., and Arnold, F.: Deployment 
of a ground-based CIMS apparatus for the detection of organic gases in the boreal forest during the QUEST campaign, Atmos. Chem. Phys., 5, 357-372, 2005a, http://www.atmos-chem-phys.net/5/357/2005/.

Sellegri, K., Umann, B., Hanke, M., Arnold, F., and Kulmala, M.: Measurements of organic gases during aerosol formation events in the boreal forest atmosphere during QUEST, Atmos. Chem. Phys., 5, 373-384, 2005b, http://www.atmos-chem-phys.net/5/373/2005/.

Shimmo, M., Jäntti, J., Aalto, P., Hartonen, K., Hyötyläinen, T., Kulmala, M., and Riekkola, M.-L.: Characterisation of organic compounds in aerosol particles from a Finnish forest by on-line coupled supercritical fluid extraction-liquid chromatography-gas chromatography-mass spectrometry, Anal. Bioanal. Chem., 378, 1982-1990, 2004.

Sinha, V., Williams, J., Crutzen, P., and Lelieveld, J.: Methane emissions from boreal and tropical forest ecosystems derived from in-situ measurements, Atmos. Chem. Phys. Discuss., 7, 14011-14039, 2007, http://www.atmos-chem-phys-discuss.net/7/14011/2007/.

Spanke, J., Rannik, U., Forkel, R., Nigge, W., and Hoffmann, T.: Emission fluxes and atmospheric degradation of Monoterpenes above a boreal forest: field measurements and modeling, Tellus B, 53, 406-422, 2001.

Taipale, R., Ruuskanen, T. M., Rinne, J., Kajos, M. K., Hakola, H., Pohja, T., and Kulmala, M.: Technical Note: Quantitative long-term measurements of VOC concentrations by PTR-MS measurement, calibration, and volume mixing ratio calculation methods, Atmos. Chem. Phys., 8, 6681-6698, 2008,

http://www.atmos-chem-phys.net/8/6681/2008/.

Tunved, P., Hansson, H.-C., Kerminen, V.-M., Ström, J., Dal Maso, M., Lihavainen, H., Viisanen, Y., Aalto, P. P., Komppula, M., and Kulmala, M.: High Natural Aerosol Loading over Boreal Forests, Science, 312, 261-263, 2006.

Väkeva, M., Hämeri, K., Puhakka, T., Nilsson, E. D., Hohti, H., and Mäkela, J. M.: Effects of meteorological processes on aerosol particle size distribution in an urban background area., J. Geophys. Res., 105, 9807-9821, 2000.

Vana, M., Kulmala, M., Dal Maso, M., Horrak, U., and Tamm, E.: Comparative study of nucleation mode aerosol particles and intermediate air ions formation events at three sites, J. Geophys. Res.-Atmos., 109, 201, 2004.

Vesala, T., Haataja, J., Aalto, P., Altimir, N., Buzorius, G., Garam, E., Hämeri, K., Ilvesniemi, H., Jokinen, V., Keronen, P., Lahti, T., Markkanen, T., Mäkelä, J. M., Nikinmaa, E., Palmroth, S., Palva, L., Pohja, T., Pumpanen, J., Rannik, U., Siivola, E., Ylitalo, H., Hari, P., and Kulmala, M.: Long-term field measurements of atmospheresurface interactions in boreal forest combining forest ecology, micrometeorology, aerosol physics and atmospheric chemistry, Trends in Heat, Mass, Momentum Transfer, 4, 17-35, 1998.
Vesala, T., Suni, T., Rannik, Ü., Keronen, P., Markkanen, T., Sevanto, S., Grönholm, T., Smolander, S., Kulmala, M., Ilvesniemi, H., Ojansuu, R., Uotila, A., Levula, J., Mäkelä, A., Pumpanen, J., Kolari, P., Kulmala, L., Altimir, N., Berninger, F., Nikinmaa, E., and Hari, P.: Effect of thinning on surface fluxes in a boreal forest, Global Biogeochem. Cy., 19, 1-11, 2005.

Weber, R. J., McMurry, P. H., Mauldin, R. L., Tanner, D. J., Eisele, F. L., Clarke, A. D., and Kapustin, V. N.: New particle formation in the remote troposphere: A comparison of observations at various sites, Geophys. Res. Lett., 26, 307-310 1999.

Williams, J., Yassaa, N., Bartenbach, S., and Lelieveld, J.: Mirror image hydrocarbons from Tropical and Boreal forests, Atmos. Chem. Phys., 6, 973-980, 2007, http://www.atmos-chem-phys.net/6/973/2007/.

Yassaa, N. and Williams, J.: Analysis of enantiomeric and nonenantiomeric monoterpenes in plant emissions using portable dynamic air sampling/solid-phase microextraction (PDAS-SPME) and chiral gas chromatography/mass spectrometry Atmos. Environ., 39, 4875-4884, 2005.

Yassaa, N. and Williams, J.: Enantiomeric monoterpene emissions from natural and damaged Scots pine in a boreal coniferous forest measured using solid-phase microextraction and gas chromatography/mass spectrometry, J. Chromatography A, 1141, 138-144, 2007.

Yu, J. Z., Griffin, R. J., Cocker, D. R., Flagan, R. C., Seinfeld, J. H., and Blanchard, P.: Observation of gaseous and particulate products of monoterpene oxidation in forest atmospheres, Geophys. Res. Lett., 26, 1145-1148, 1999.

Zhang, R., Suh, I., Zhao, J., Zhang, D., Fortner, E. C., Tie, X., Molina, L. T., and Molina, M. J.: New particle formation enhanced by organic acids, Science, 304, 1487-1490, doi:10.1126/science.1095139, 2004.

Zimmerman, P. R., Greenberg, J. P., and Westberg, C. E.: Measurements of atmospheric hydrocarbons and biogenic emission fluxes in the Amazon boundary layer, J. Geophys. Res., 93, 1407-1416, 1988 . 